\title{
13.2 SEDIMENTOLOGY AND ENVIRONMENTAL CONDITIONS OF SAPROPELS
}

\author{
Walter Sigl, ${ }^{1}$ Hervé Chamley, ${ }^{2}$ Frank Fabricius, ${ }^{1}$ Ghislaine Giroud d'Argoud, ${ }^{2}$ and Jens Müller ${ }^{1}$
}

\begin{abstract}
Color (lightness), organic carbon content, total nitrogen content, carbonate content, and bulk and clay mineralogy were determined for most of the sapropelic sediments recovered by Leg $42 \mathrm{~A}$ and for some of their adjacent normal sediments.

Maximum values of organic carbon and nitrogen reach $16.7 \%$ and $1 \%$, respectively. Carbon/nitrogen ratios generally increase with greater organic carbon content and with increasing age. Very high ratios of some sapropel material suggest a considerable supply of terrigenous organic material.

The color of the sediment becomes darker with increasing organic carbon content. This is interpreted as the result of monosulfide formation which is controlled by the original content of finely dispersed organic matter. In contrast, the formation of pyrite in sapropels seems to depend upon the presence or absence of lumps of organic matter.

Total carbonate content ranges between almost zero and $78 \%$ in the sapropels. In comparison to normal sediments, no major carbonate dissolution could be observed. Calcite is the dominant carbonate mineral, while the content of detrital dolomite reaches a maximum of $16 \%$. Occasionally, appearances of calcite and aragonite are attributed to turbiditic supply of shallow water carbonates. In the Messinian evaporitic sequence of Site 374, primary or early diagenetic dolomite is the only carbonate mineral.

Calcite, mainly derived from the tests of foraminifers and coccolithophorids; has no relation to the content of organic carbon. This, together with the abundance of plant debris, suggests that the main part of the organic material in sapropels does not originate from plankton.

Gypsum is a common component of sapropels, while anhydrite is restricted to the evaporitic sediments of Messinian age. For these strata, contemporaneous formation of sulfides (pyrite) and sulfates (gypsum, anhydrite) is assumed.

The clay mineralogy of the sapropel shows considerable differences from that of the normal host sediments: greater contents of organic matter result in increased mineral alteration. The alteration leads to a degradation of the minerals towards mixed-layer types or chlorite, or to their complete destruction. The process increases in the series: kaolinite, illite, chlorite, smectite, attapulgite. The degree of alteration is greatest at the bases of sapropels. It appears to occur when a rich supply of detrital fragile materials has been available to sites in the center of the sapropelic area in the deeper parts of the basin. It is clear that the mechanisms of sapropel formation operate at the sediment/seawater interface and do not depend on depth of burial.
\end{abstract}

\section{INTRODUCTION}

So-called sapropels are the most striking individual layers found within cores of Pliocene to Quaternary age from the eastern Mediterranean. Since they are interbedded as dark layers in more or less normal light "open marine" sediments, the formation of these layers is commonly referred to short-lived but cata-

1 Technical University of Munich, Arcisstrasse 21, D 8 Munich, Federal Republic of Germany.

2 Oceanographic Institute, Luminy, 13288 Marseilles cx 2, France. strophic alterations in oceanographic conditions probably caused by climatic changes. Bradley (1938) predicted (without having cores as evidence) the occurrence of episodes of stagnation during Quaternary time (of the Mediterranean basins). In 1948, his hypothesis was verified by the cores of the Swedish Deep Sea Expedition. Using these cores, Kullenberg (1952) discussed the problem of sapropel formation in regard to interstitial salinity variations. Later, Olausson (1961) presented a model of sapropel formation which depending on the authors' viewpoint, has subsequently been variously improved, supplemented, or rejected by, for example, Chamley, 1971; Miller, 1972; Ryan, 1972; Nesteroff, 1973; McCoy, 1974; Cita et al., 1973. 
Today, Olausson's classic glacio-eustatic model is no longer sufficient to explain all aspects of sapropel formation. Differing faunal and lithological characteristics within sapropelic layers of different ages suggest mechanisms of sapropel formation. Brongersma-Sanders (1957) stated that bituminous rocks may be formed when "either the supply of oxygen to the lower water layers is excessively low (persistent stagnation), or the supply of dead plankton and other oxidizable material is extremely high (hypertrophy)." This may help explain the occurrence of sapropelic sediments in "preglacial" lower Pleistocene and upper Pliocene sediments recovered by DSDP Leg 13 (Ryan, Hsü et al., 1973; Cita, 1973), as well as others in Miocene cores recovered by Leg $42 \mathrm{~A}$. Moreover, the discovery of sapropelic sediments in the western Mediterranean (Kidd et al., this volume) proved that this phenomenon is not entirely restricted to the eastern basin as has been assumed to date. Therefore, new conceptions of the mechanism of sapropel formation should be taken into consideration.

In order to examine further Mediterranean sapropel formation, more exact definition of the term "sapropel" appears necessary. Up to now, sapropels in Mediterranean cores have been recognized mainly by their dark color, by their content of microscopically detectable "organic matter," and by the absence or rareness of benthic fossils or bioturbation.

There is no doubt that the original definition of a "sapropel" has genetic and environmental implications: a sediment rich in organic matter which has been formed under reducing conditions (an $\mathrm{H}_{2} \mathrm{~S}$ environment) in a stagnant water body (Wasmund, 1930; Pontoniè, 1937). The boundary between oxygenated and stagnant anoxic water masses is variously placed somewhere in the water column, and any alteration of the organic matter is restricted to the activity of anaerobic bacteria.

In contrast to sapropel, the term "gyttja" is used for high-organic sediments which are formed in water containing oxygen down to the sea bottom. Therefore, gyttja often shows distinct traces of benthic life. The decomposition of the organic matter in the gyttja facies was prevented by either too low a content of oxygen in the water or by too high a rate of sedimentation. Both, sapropel and gyttja, are considered to be "sapropelites," a term which is commonly used for bituminous fossil rocks (Potoniè, 1937). The distinction into "sapropel" (sensu stricto) and gyttja for Mediterranean " sapropelites" with respect to the environmental conditions during formation is difficult. Therefore, the use of the term sapropel has mainly a qualitative and descriptive meaning.

In order to obtain a more precise nomenclature of organic sediments in the Mediterranean, the content of organic matter, expressed as the content of organic carbon (org. C), should be included in the definition. Olausson (1961) already defined "sapropelic muds" as "black deposits with high content of organic matter, $>2 \%$ C." Detailed analyses of the organic carbon content in sediments with increased organic carbon in cores of the eastern Mediterranean (Sigl and Müller, in press; Sigl, in preparation) showed a close relation between sediment color and organic carbon content. The most significant changes in color generally occur at $0.5 \%$ (brown to gray) and $2.0 \%$ (gray to black).

Based on these results, the following nomenclature was adopted:

\begin{tabular}{cll}
\hline $\begin{array}{c}\text { Organic Carbon } \\
\text { Content (\%) }\end{array}$ & $\begin{array}{c}\text { Sedimentological } \\
\text { Nomenclature }\end{array}$ & \multicolumn{1}{c}{ Color/Texture } \\
\hline $0-0.5$ & $\begin{array}{l}\text { Normal oxygenated } \\
\text { sediment }\end{array}$ & $\begin{array}{l}\text { Brown or light (olive) } \\
\text { gray, of ten homogenized, } \\
\text { generally burrowed } \\
\text { Significant color change } \\
\text { (in general) }\end{array}$ \\
$0.5-2.0$ & $\begin{array}{l}\text { Sapropelic sediment } \\
\text { (fossil : sapropelitic) }\end{array}$ & $\begin{array}{l}\text { Olive and/or gray, often } \\
\text { with burrowing traces } \\
\text { Significant color change } \\
\text { (in general) }\end{array}$ \\
& Sapropel & $\begin{array}{l}\text { Olive and/or gray to } \\
\text { black, of ten warve-like } \\
\text { lamination }\end{array}$ \\
\hline
\end{tabular}

${ }^{a}$ Note that this nomenclature differs slightly from that used in the preceding contribution (Kidd et al., this volume), which restricts its use to open marine sediment sequences.

bTo discriminate recent and fossil sediments rich in organic C, Olausson (1961) used the indicated differentiation of terms.

The terms "sapropelic" and "sapropel," proposed here, have no genetic significance. They can be applied for all organic sediments independently of their stratigraphic or genetic position. The given limits of organic carbon content are appropriate to Mediterranean sediments. In other marine basins these limits might be placed differently.

\section{ANALYTICAL METHODS}

The color of the sediments was determined by comparison with the GSA Rock Color Chart (Goddart, 1963). For correlation of sediment color and organic carbon content, the lightness of the colors ("value") was used. This is divided into 10 degrees: low values for dark colors and vice versa. Organic carbon was measured with a Leco Carbon Analyzer; total nitrogen was determined by the standard micro-Kjeldahl method (See Sigl, 1977). Carbonate and bulk mineralogy was analyzed by X-ray diffractometry (see Muller, 1977). For analysis of clay minerals, see Mélières et al. (this volume).

\section{RESULTS}

Figures 1 to 3 show a synopsis of color determination, organic carbon and nitrogen analyses, carbonate, bulk and clay mineralogy for most of the sapropelic layers, and sapropels in cores of Leg $42 \mathrm{~A}$ and for some of the adjacent normal sediments.

Not all of the dark layers as listed in the Leg 42A sarpopel stratigraphy (Kidd et al., this volume) were analyzed, but the figures also include analyses of mudstones in the Messinian evaporitic sequence of Site 374 (Figure 1). At Site 373A (Tyrrhenian basin) a highly deformed lump of black organic-rich sediment was found in Core 1. Analyses of this sediment (373A- 
$1-2$ ) yielded organic carbon contents up to $2.1 \%$ (Sigl, this volume), thus confirming it as a sapropel.

\section{Color}

Leg 42A sapropels and sapropelic sediments show a close relationship between sediment color (lightness value) and organic carbon content (Figures 1 to 3 ). This correspondence becomes more marked as organic carbon content increases. With a few exceptions, normal sediments give values between 8 and 4 , sapropelic ones between 6 and 3, and sapropels between 4 and 1 .

\section{Organic Carbon and Total Nitrogen Contents}

Organic carbon content reaches a maximum value of $16.7 \%$ in a Pliocene sapropel of Site 374 (Sample $5-3,49-53 \mathrm{~cm}$ ). To date, this is the highest value recorded for Mediterranean cores known to the authors. It occurs in the upper third of a sapropel which is only $4 \mathrm{~cm}$ thick. Other thin sapropels (2 $\mathrm{cm}$ thick) show extremely high values also (e.g., $9.9 \%$ in Sample 374-5-3, 9-10 cm).

Sites 374 to 378 , Pleistocene and Pliocene sapropels are much alike in their organic carbon content, often reaching more than $5 \%$. The data of Sites 374,376 , and 378 suggest a general downhole decrease in organic carbon content, although such trends must be treated carefully because of incomplete coring and arbitrary sampling. In the Messinian of Site 374, sapropels (in terms of the above definition) occur in Cores 16, 17, and 20 (Figure 1). At Site 375 (Sample $4-4,40-62 \mathrm{~cm}$ ) a sapropel of Tortonian age shows contents of organic carbon up to $>7 \%$ (Figure 2). In the middle Miocene strata of Site 377 values are considerably lower. Three samples with organic carbon contents characteristic of sapropels were recognized (Figure 1).

Most of the sapropels have nitrogen contents greater than $0.2 \%$, while in sapropelic sediments nitrogen varies between $0.08 \%$ and $0.2 \%$. Total nitrogen reaches maximum values of $1 \%$ in sapropel $374-5-3,49-53 \mathrm{~cm}$, which also shows the highest organic carbon content measured.

Generally, total nitrogen increases with increasing organic carbon, that is organic matter. However, the relative increase in nitrogen is not as great as the increase in organic carbon. This is documented by increasing $\mathrm{C} / \mathrm{N}$ ratios from normal through sapropelic to sapropel sediments (Figure 4).

In general, Messinian sapropels and sapropelic sediments of Site 374 have higher $\mathrm{C} / \mathrm{N}$ ratios than Pliocene ones, and Pliocene sapropels show higher ratios again than Pleistocene ones. An outstandingly high ratio (26.7) occurs in Messinian sapropel 374-17$1,72-75 \mathrm{~cm}$. The $\mathrm{C} / \mathrm{N}$ ratios of Sites 374 and 376 are generally higher than those of Site 374 . In samples of Sites 377 and 378 nitrogen content was not analyzed.

\section{Carbonate Mineralogy}

For the Pliocene-Pleistocene sapropels and sapropelic sediments of Site 374, total carbonate content ranges between almost zero in Sample 5-3, 49-53 cm, to more than $60 \%$. Carbonate content increases downhole towards the base of the Pliocene. There, a maximum of $78 \%$ occurs (Core 11). Below, the Messinian sediments, rich in organic carbon contain much less carbonate. Sites 375 and 376 show similar changes, although fewer samples could be analyzed. In the Tortonian (upper Miocene) and Serravallian (middle Miocene) total carbonate content drops to less than $10 \%$. Quaternary sapropels of Site 378 have total carbonate contents of greater than $50 \%$, while Pliocene ones stay below this value. Sometimes less than $25 \%$ total carbonate was determined. Generally, no significant differences exist between sapropels and normal sediments, either in total carbonate content or in carbonate mineralogy. However, it is clear that within a given sapropel layer, the carbonate content can vary considerably (e.g., Sample 375-4-4, 40-64 cm).

While calcite is the dominant carbonate mineral in Pliocene-Pleistocene sapropels of Site 374, those from the Messinian and earliest Pliocene strata contain exclusively dolomite. Dolomite (up to $16 \%$ ) has been found also in many Pliocene-Pleistocene samples of Site 374. The carbonate in Sample 374-21-1, 105-108 $\mathrm{cm}$ (Messinian) consists exclusively of magnesite, as well as the dominant calcite, most of the sapropel and sapropelic layers of Sites 375 and 376 show the presence of dolomite in significant amounts (up to 9\%), sometimes accompanied by $\mathrm{Mg}$-calcite. The same phenomenon occurs in a few samples of Site 377. In Holes 378 and $378 \mathrm{~A}$, dolomite is generally rare, but also reaches values up to $9 \%$.

\section{Bulk Mineralogy}

Pyrite and gypsum are characteristic minerals of sapropels, whereas these minerals are often lacking in sapropelic layers. There is no significant relation between the amount of pyrite or gypsum and organic carbon in the samples analyzed from Leg 42A. In the Messinian evaporitic sediments of Site 374 , gypsum is a common component and not restricted to sapropels or sapropelic layers. In sapropels of Cores 17 to 21 , anhydrite occurs in considerable amounts.

Quartz, feldspar, and plagioclase are rare in the Messinian samples of Site 374. In the sapropels of younger strata higher values of these minerals generally coincide with a low content of total carbonate (e.g., Sample 5-3, 49-53 cm), and sometimes with considerable amounts of dolomite (e.g., Sample 5-2, $33-34 \mathrm{~cm})$.

\section{Clay Mineralogy}

\section{Site 374}

The normal sediments of Pleistocene age here are characterized by a dominance of smectite $(65 \%)$, less kaolinite $(20 \%)$, and illite (15\%), and only traces of chlorite and mixed-layers. Attapulgite is rare or its presence is doubtful. The interbedded sapropels show moderately less smectite and poorly crystallized illite particles, but increased amounts of the irregular mixedlayers smectite-illite, smectite-chlorite and one type of chlorite. These differences are less distinct in the 


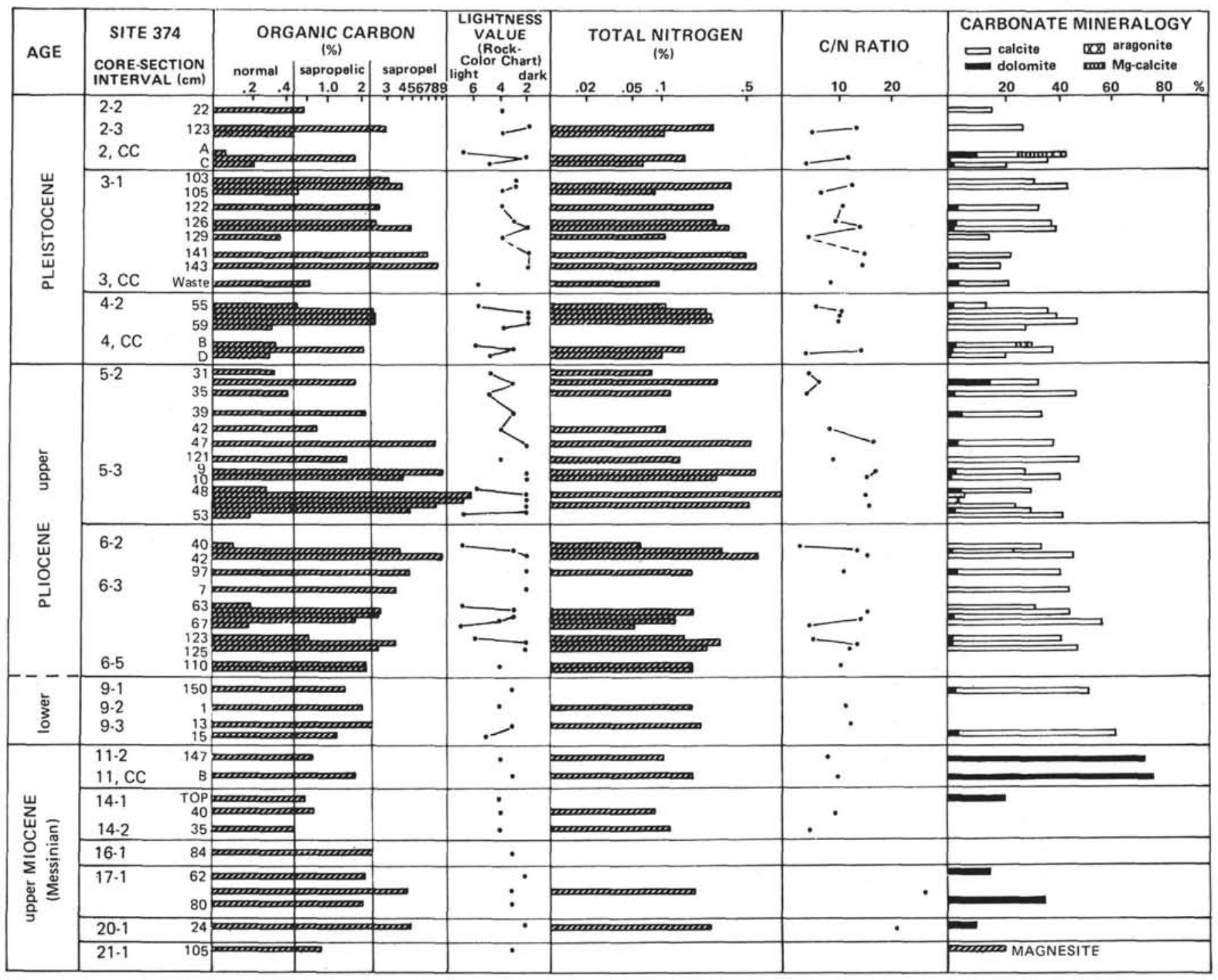

SITE 377

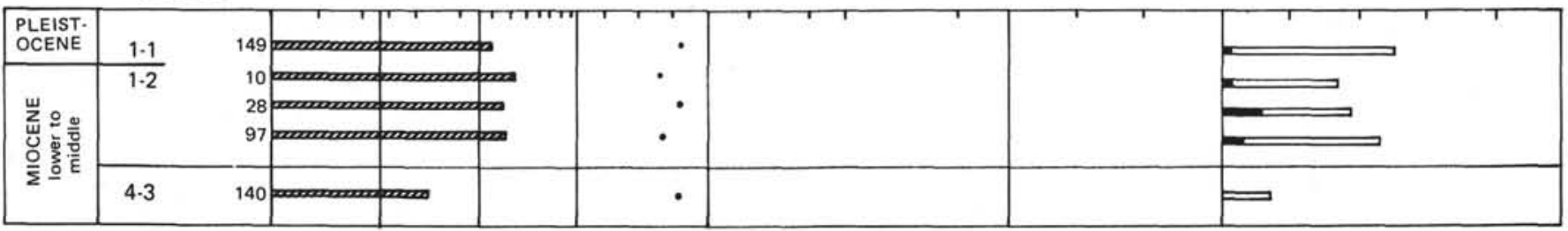

Figure 1. Organic carbon (org. C), nitrogen ( $N$ ) content, and mineralogical composition of sapropelic sediments and sapropels of Sites 374 and 377, Ionian Sea, with some additional "normal" sediments.

sapropel of Sample 2, CC, but rather significant and with an accentuation toward the base in sapropel 4-2, $55-59 \mathrm{~cm}$.

The normal Pliocene sediments are characterized by a relative abundance of attapulgite $(25 \%-50 \%)$, followed by smectite $(30 \%)$, illite $(15 \%)$, kaolinite $(15 \%)$, chlorite (5\%), and traces of mixed-layer types. Pliocene sapropels, in contrast, differ in that they contain little or no attapulgite. This is most significant in sapropels of Core 5 (e.g., Sample 5-3, 49-53 cm). The older sapropels of Cores 6 and 9 show only slight to moderate differences to the adjacent normal sediments. The sapropels and sapropelic strata of Messinain age (Cores 12 to 17) show no mineralogical peculiarity with respect to the clay fraction.

\section{Site 375}

The normal sediments of upper Tortonian age at this site contain a clay fraction of smectite ( $50 \%)$, illite, chlorite and attapulgite ( $15 \%$ each), and small 


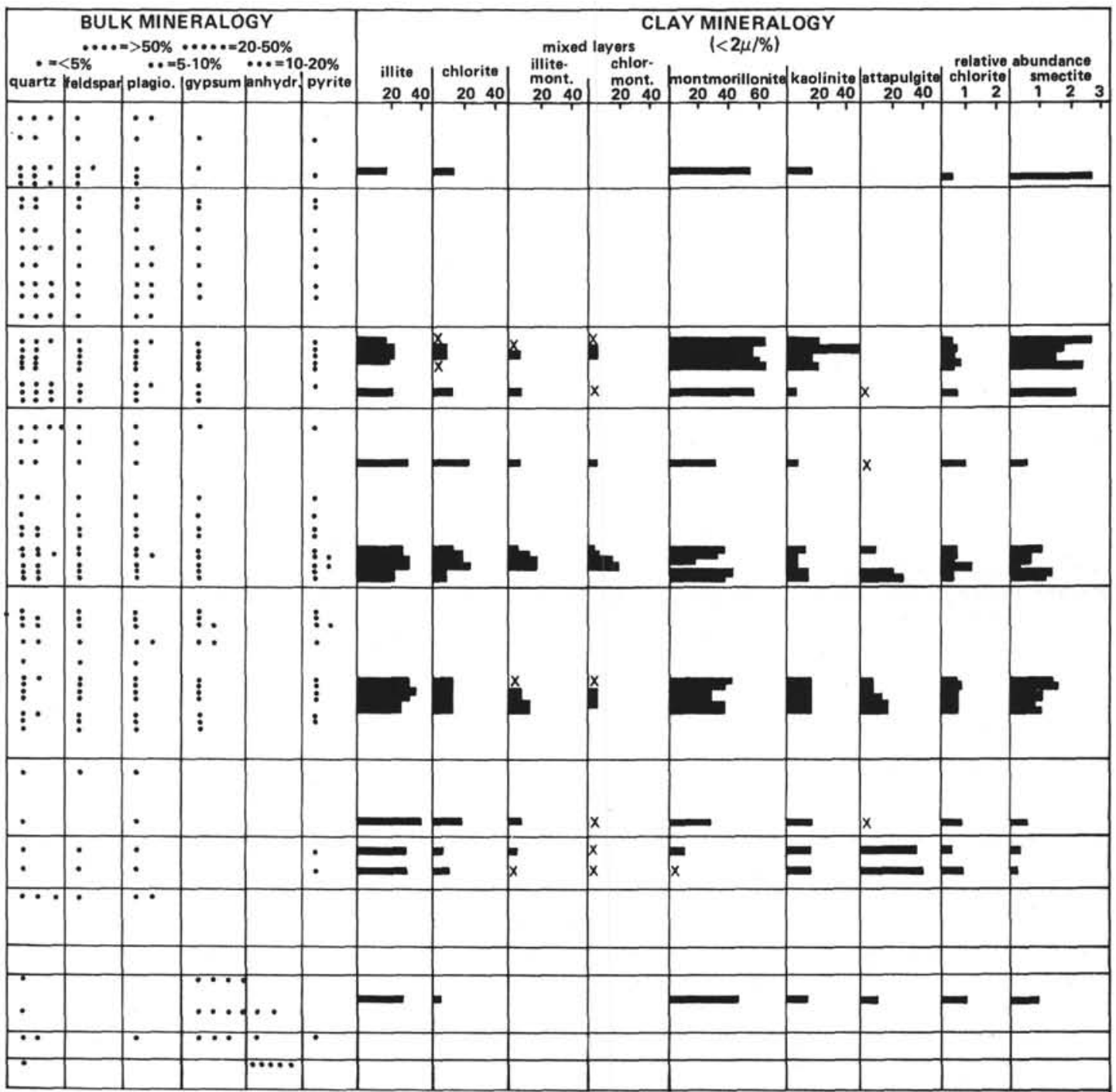

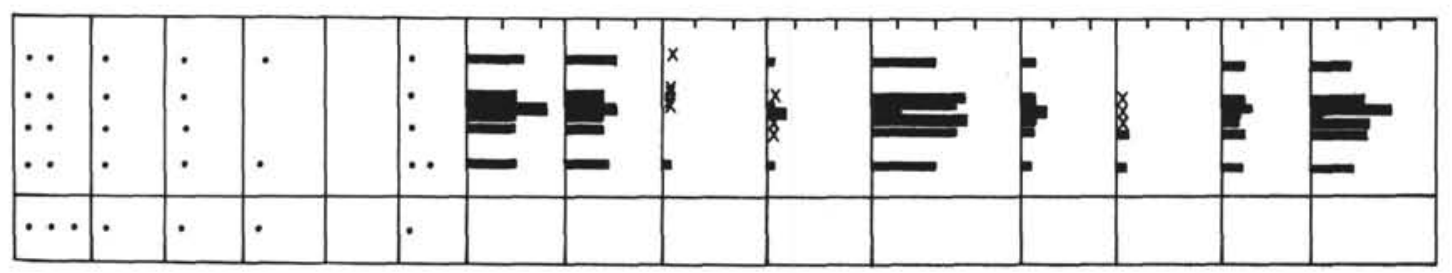

Figure 1. (Continued).

amounts of kaolinite. The clays of the intercalated sapropels and sapropelic layers contain attapulgite, and few more mixed-layer types. Also smectite occurs in a less crystallized form.

\section{Site 376}

At this site, in the Quaternary sediments smectite is the most abundant clay mineral ( $80 \%$ and more), while illite, chlorite, kaolinite, and attapulgite make up the remainder ( $5 \%$ each). The sapropelic levels show small but systematic differences: smectite is less abun- dant as is attapulgite, while mixed-layer types (illitesmectite, chlorite-smectite, and chlorite) are present in greater amounts. The illite varies little in abundance and crystallinity. The changes in the abundance of attapulgite, smectite, and mixed-layer minerals, in comparison to normal sediments, are generally comparable at different levels within a given sapropel. A trend of increasing degradation towards the base is obvious only in Core 1. In Miocene strata (Core 12), no difference in respect of the clay minerals could be observed between normal and sapropelic sediments. 


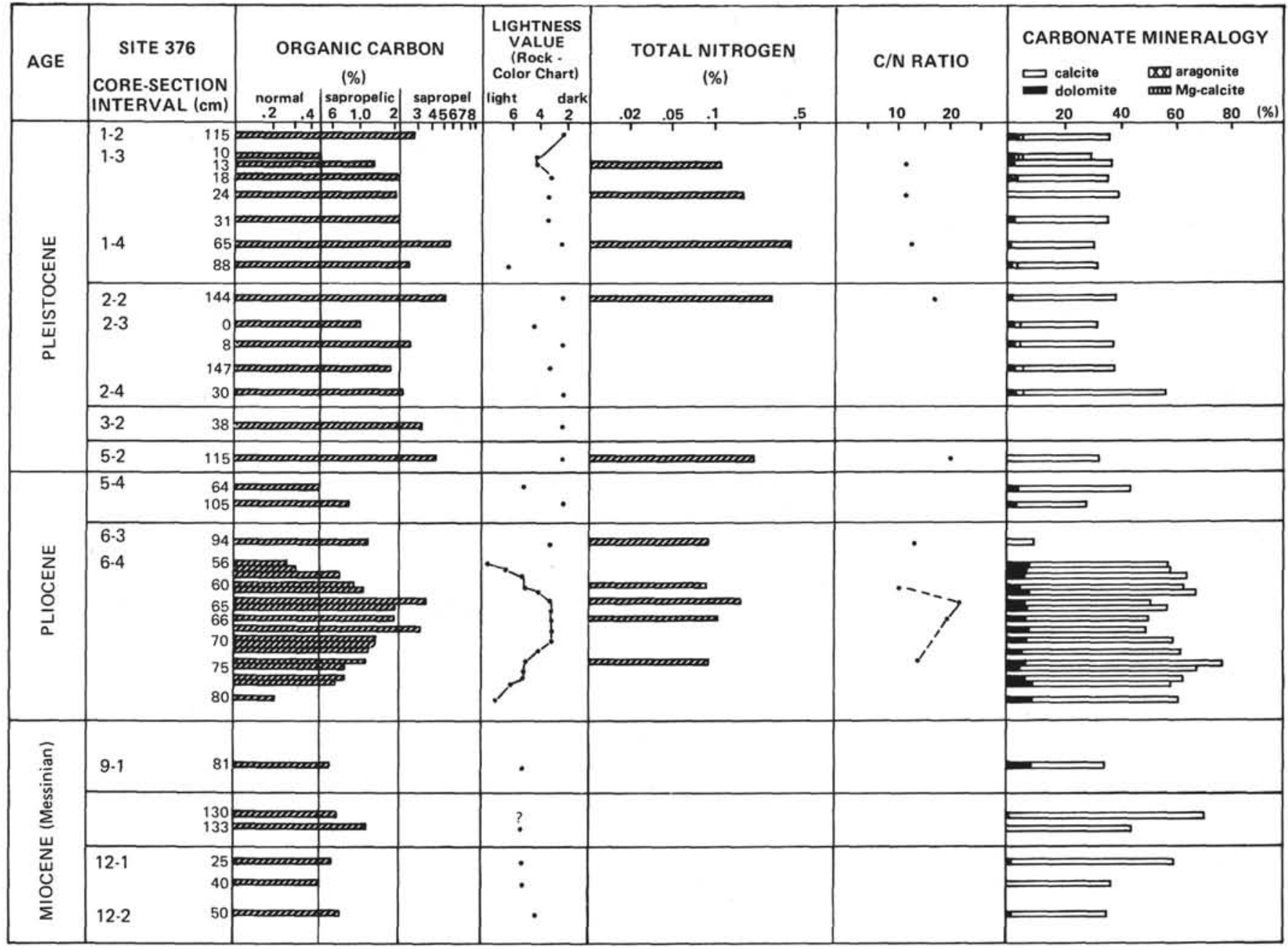

SITE 375

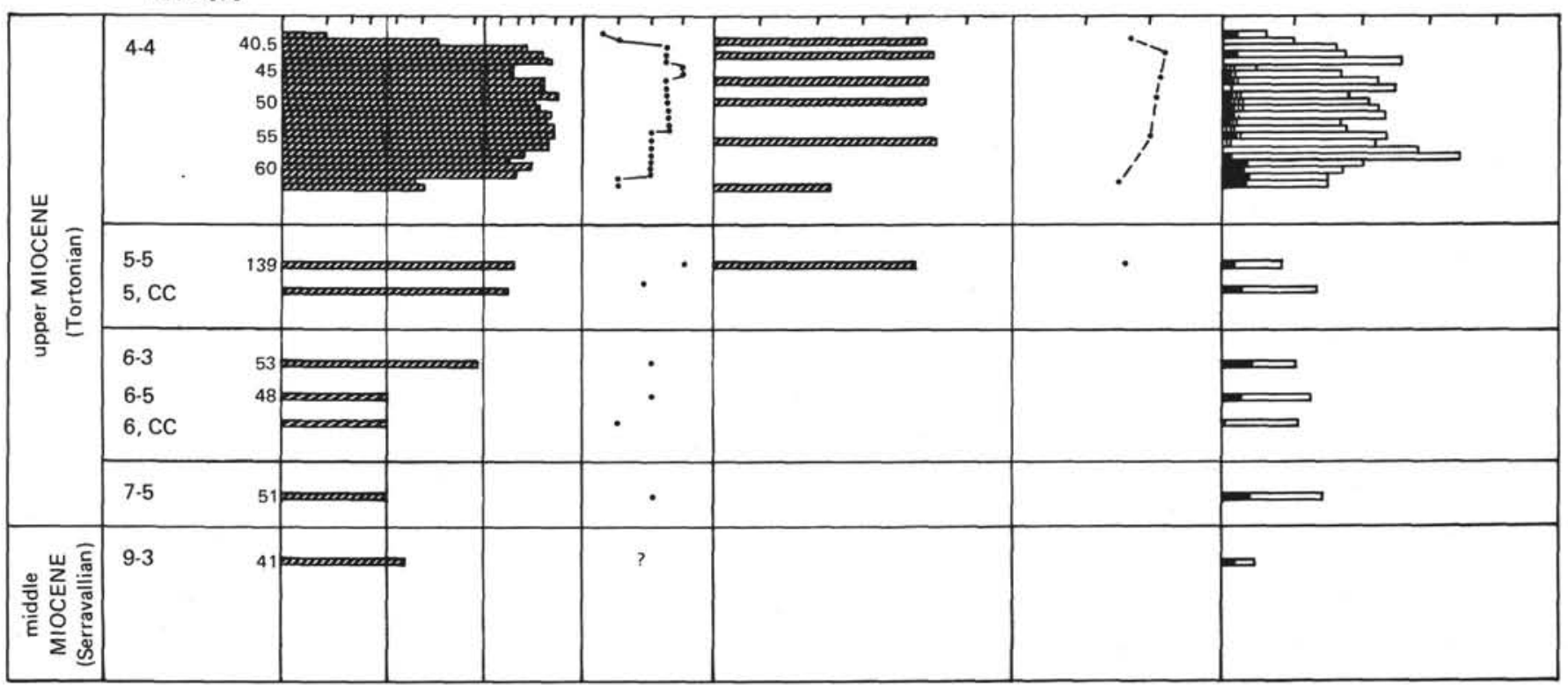

Figure 2. Organic carbon (org. C), nitrogen $(N)$ content, and mineralogical composition of sapropelic sediments and sapropels of Sites 375 and 376, Florence Rise, Levantine Sea, with some additional "normal" sediments. 

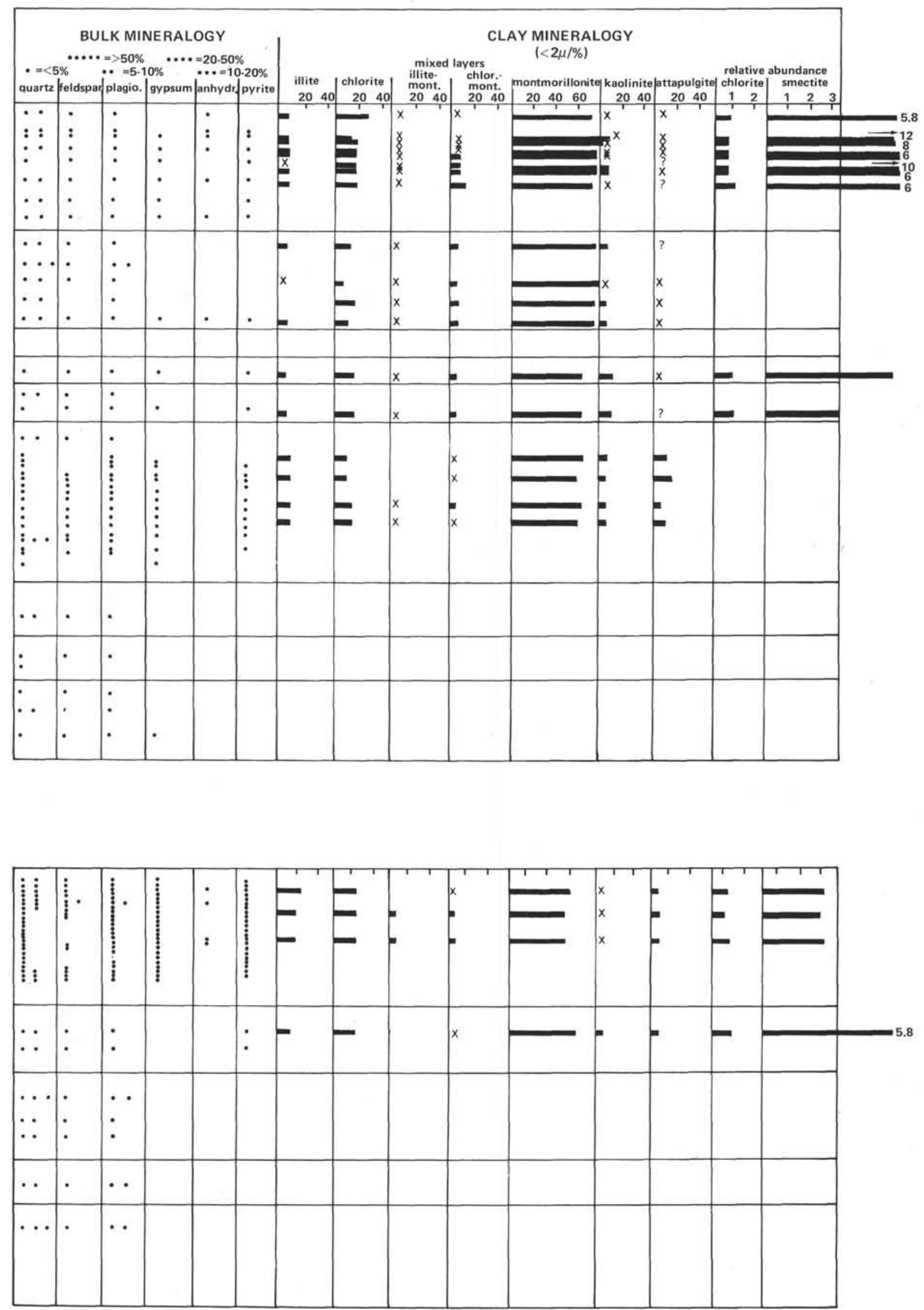

Figure 2. (Continued). 


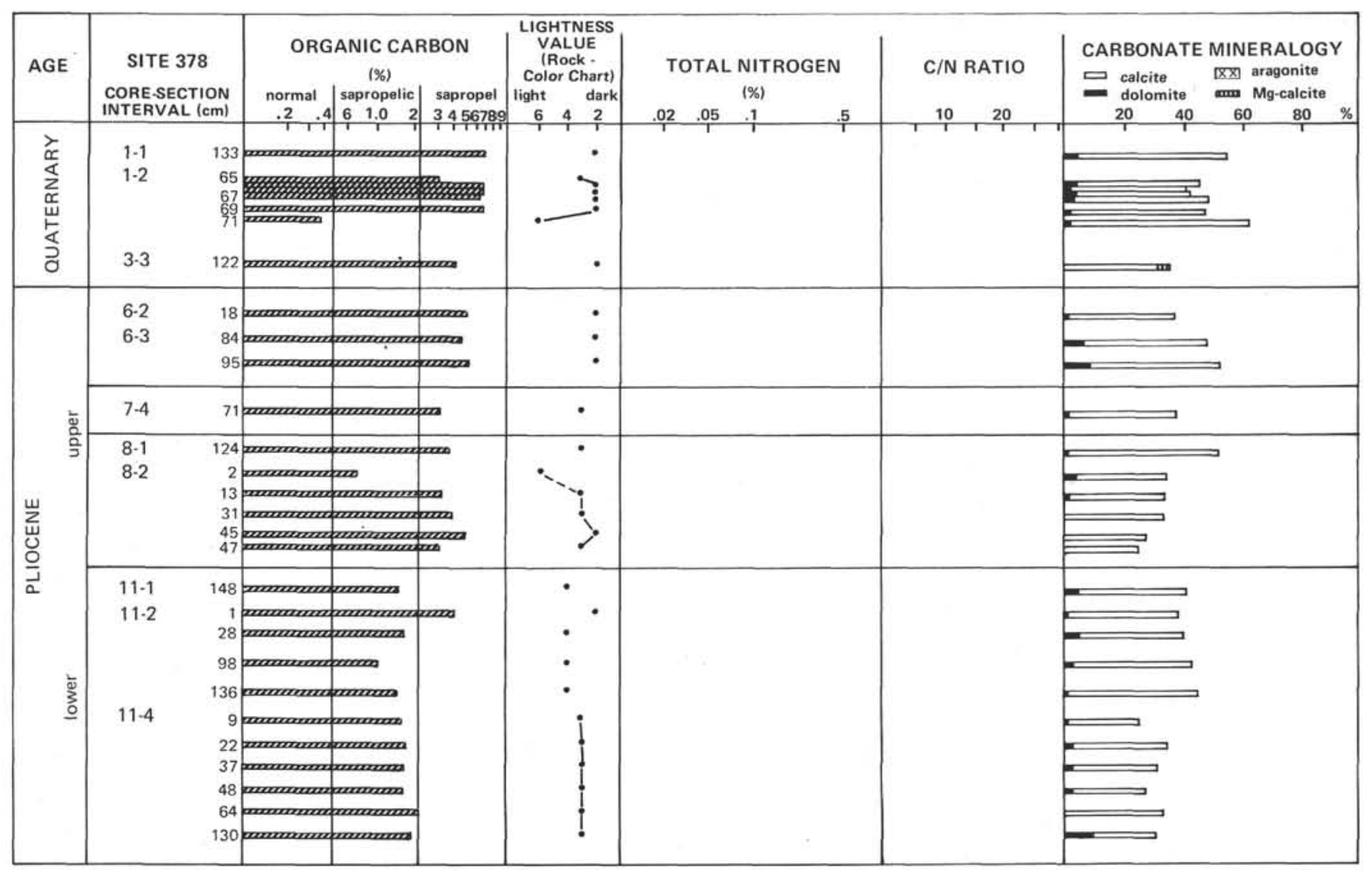

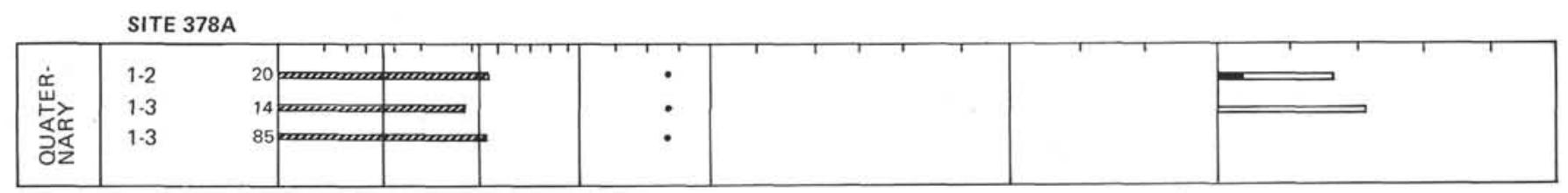

Figure 3. Organic carbon (org. C) content and mineralogical composition of sapropelic sediments and sapropels of Holes 378/ 378 A, southern Aegean Sea, with some additional "normal" sediments.

Site 377

The clay fraction of normal lower Pleistocene sediments at Site 377 (Core 1) contains about 50\% smectite, $25 \%$ illite, $20 \%$ chlorite, $5 \%$ kaolinite, and traces of attapulgite. Within the sapropels, the irregular mixedlayer types seem to increase at the expense of smectite. Attapulgite content diminishes and abundant but badly crystallized illite particles are present.

\section{Holes 378 and $378 \mathrm{~A}$}

In these holes both the Pliocene and Pleistocene clays are characterized by abundant well-crystallized smectite $(60 \%)$, significant amounts of illite and chlorite (15\%-20\% each), and only a little kaolinite. Differences between the sapropels and normal sediments occur with variable intensity and are independent of core depth. They are as follows:

Very weak: little increase in.mixed-layer types, smectite poorly crystallized (Holes 378, Cores 7 and 11; 378A, Core 1).
Weak: moderate decrease in smectite, but slight increase in mixed-layer minerals (Holes 378 , Cores 3 and $6 ; 378 \mathrm{~A}$, Core 3 ).

Moderate: significantly less smectite together with open illite (Hole 378, Core 8).

Strong: much less smectite in comparison with illite (Hole 378, Core 1); variations in their amounts are greater toward the base of the sapropel; transitional minerals (mixed-layers) are absent; smectite occurs in weathered form and the conservation of illite and chlorite affects large-size particles only.

\section{DISCUSSION}

\section{Sediment Color, Organic Carbon, and Pyrite}

Sediment color (lightness) has a convincing relationship to the content of organic carbon (Figures 1 to 3 ). Sigl and Müller (in press) showed that internal variations in color and organic carbon are much alike in sapropel layers of the same age but from different cores, provided that these layers are undisturbed and 

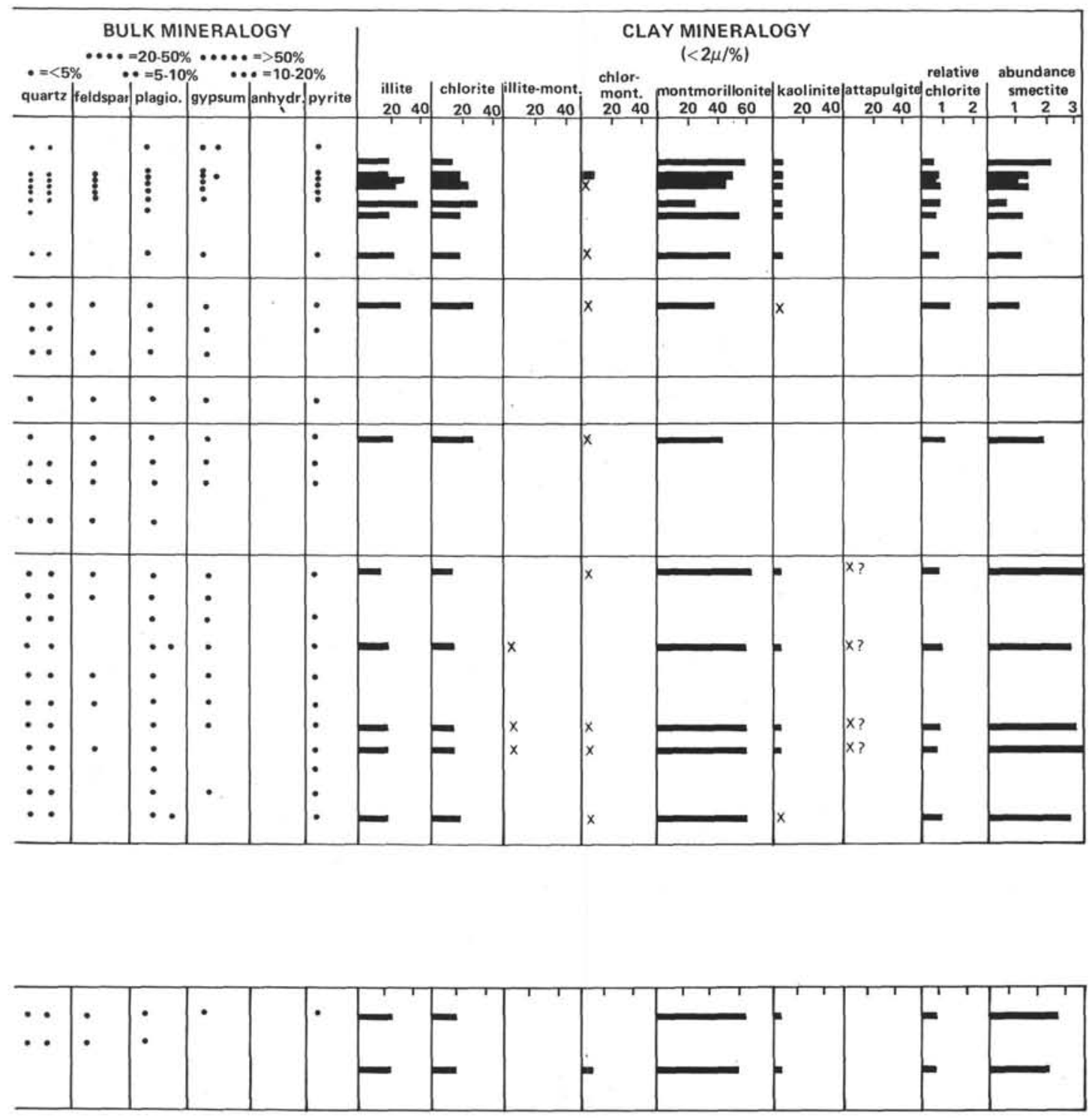

Figure 3. (Continued).

not diluted by turbiditic material. Moreover, the internal distribution curve of organic carbon of a given layer can be comparable through the whole eastern Mediterranean basin (Sigl, in preparation). It can therefore be used for lithostratigraphy.

It seems likely that variations in color and organic carbon within a sapropel document changing conditons during its formation. The possible changes are: (a) an amelioration (less stagnant) or deterioration (more stagnant) of the exchange of bottom water; (b) varying depth of the $\mathrm{H}_{2} \mathrm{~S}-\mathrm{O}_{2}$ boundary; (c) increase or decrease in the productivity in the upper water strata and/or supply of organic material at the bottom. The dark color of organic sediments is mainly caused by finely dispersed noncrystalline Fe-monosulfides which are the product of a reaction between $\mathrm{H}_{2} \mathrm{~S}$ (derived by bacterial sulfate reduction) and iron minerals in an anaerobic environment. According to Berner (1970), these monosulfides are converted to pyrite in a second step, if elemental sulfur is available. The main source of the sulfur which is necessary for these reactions, is thought to be the sulfate dissolved in seawater, since organic sulfur compounds contained in the sediment are estimated to be insufficient to provide large amounts of sulfur.

Nevertheless, the organic matter is required as an energy source for bacteria in this process: "Without metabolizable organic matter there is no sulfate reduction and no pyrite formation"' (Berner 1970, p. 13). Thus, the amount of organic matter is a controlling factor for the mechanism of iron sulfide formation. This fact is documented by the lightness of sediments which decreases with increasing content of organic carbon. In contrast, no relationship of pyrite to organic carbon content could be found in Leg $42 \mathrm{~A}$ sediments as well as in Quaternary sapropels studied to date (Sigl, in preparation). SEM-pictures show either finely dispersed iron material and/or agglomerations caused by framboidal pyrite within the monosulfide matrix. This suggests that most of the organic matter is deposited in very small but uniformly distributed grains, possibly adsorbed and/or diluted by clay minerals. If a 


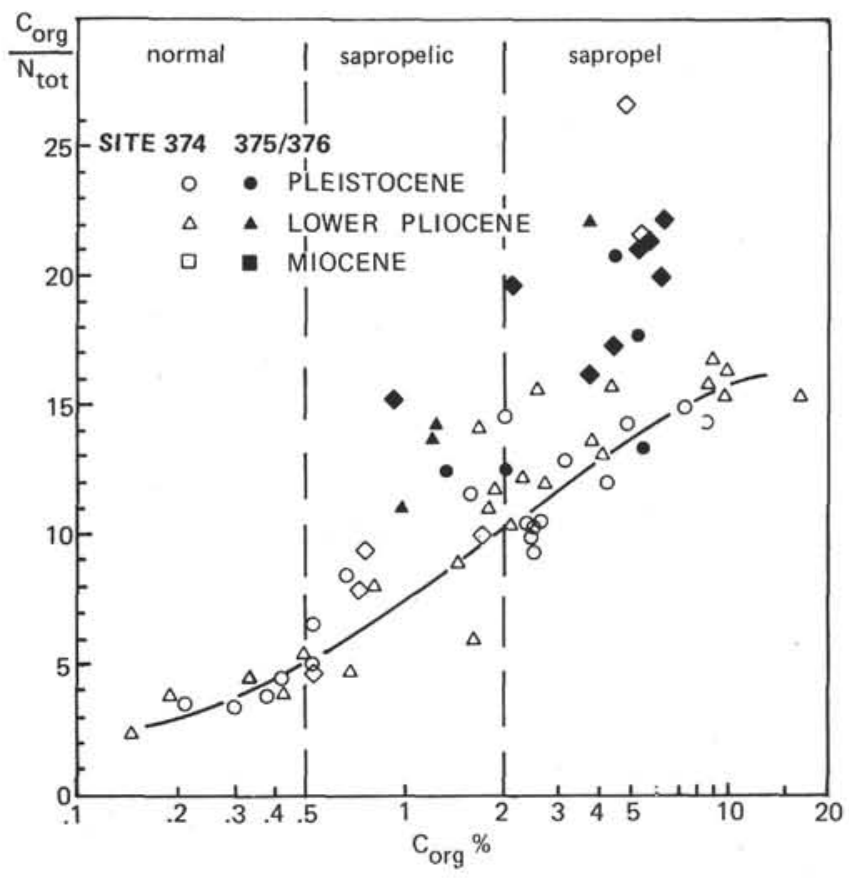

Figure 4. Relationship between organic carbon content (org. C) and the org. $C / N_{\text {total }}$ ratio of sapropels of the Ionian Sea (Site 374) and Levantine Basin (Florence Rise; Sites 375 and 376).

larger piece of organic material is incorporated in the sediment, as for instance in the case of an incompletely decomposed foraminifer (Figure 5), then this concentrated and undiluted amount of organic matter may stimulate the activity of a great number of bacteria. Thus pyritization may start. It is possible that the peculiar shape of the pyrite framboid with its exact arrangement of pyrite crystals reproduces the former arrangement of colonies of bacteria (Fabricius, 1961, Javor and Mountjoy, 1976).

\section{Organic Matter and Planktonic Organisms}

In comparison to Quaternary sapropels studied in piston cores from the eastern Mediterranean (Sigl, in preparation), sapropel layers of Leg $42 \mathrm{~A}$ are commonly thinner but show much higher organic carbon contents. They often look rather dense and coal-like. The content of organic carbon depends upon the amount of organic matter contained in the sediment and on the chemical composition of the organic compounds. For marine sediments Trask (1939) proposed a factor of 1.8 to calculate the amount of organic matter from organic carbon. Using this factor, a total organic matter content reaching up to $30 \%$ must be assumed for sapropel $374-5-3,49-53 \mathrm{~cm}$ (max. organic carbon $=16.7 \%$ ).

From the amount of carbonate and the number of calcareous tests incorporated in Leg 42A sapropels, it seems unlikely that the increased amount of organic material come from the "rain" of planktonic organisms to the sea floor. The calcite content does not show any relationship to the organic content, even though an extremely high production of plankton should neces-

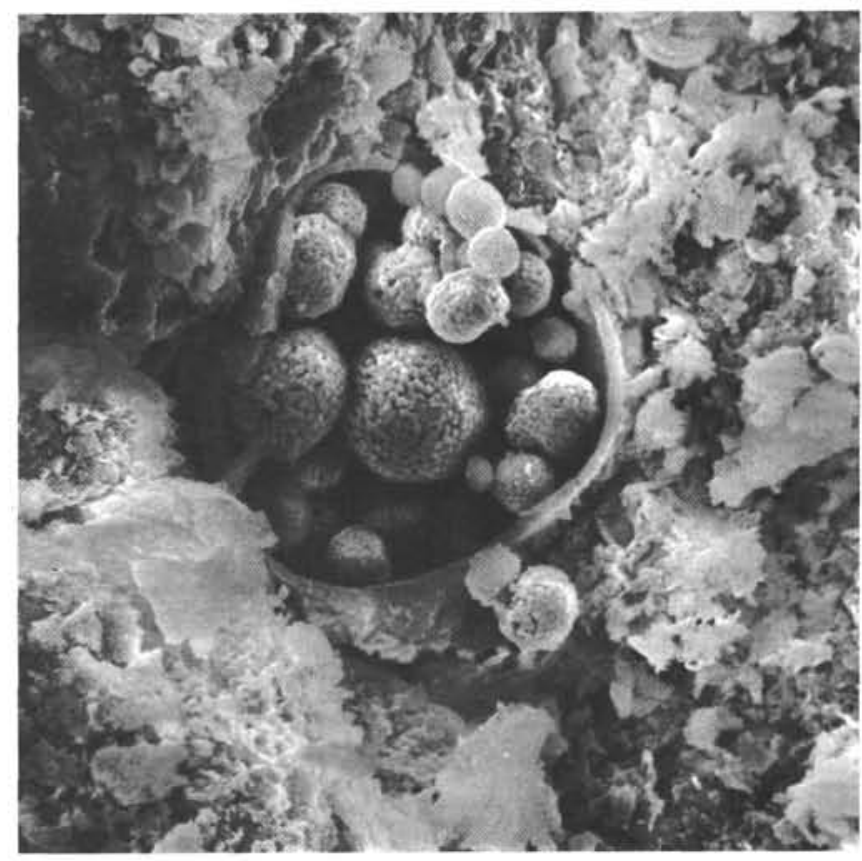

Figure 5. SEM photograph showing spheres of pyrite crystals as framboidal structures within the test of a planktonic foraminifer. The surrounding sediment is composed of carbonate and clay minerals, together with some coccoliths. Site 374 (Ionian Sea), Core 2, Section 3, 123-124 cm, Pleistocene, sapropel layer (3\% organic carbon content). $\times 870$.

sarily affect a similarly extreme accumulation of calcareous coccolithophorids and/or foraminifers. In fact, such assumulations are frequent within Quaternary sapropels ("abnormal foram fauna assemblages," Olausson, 1961), but they are practically free of organic matter (Sigl, in preparation), because of rapid decomposition of the organic material in the upper oxygenated water layers. Even in the Black Sea, the skeletal remains of planktonic organisms are deposited without organic matter (Bordovskiy, 1965).

As far as carbonate dissolution is concerned, the sapropel $374-5-3,49-53 \mathrm{~cm}$ referred to above, shows fairly well preserved coccoliths (Figure 6), while foraminifer tests are missing and skeletons of diatoms are scarce. In this sapropel, as in most Leg $42 \mathrm{~A}$ ones (Figures 7 and 8), there is no indication of considerable carbonate dissolution. In some sapropels (e.g., 3744-2, 56-58 cm, Figure 7) the calcitic tests look completely intact, while in the adjacent normal sediments (e.g., Sample 374-4-2, 75-76 cm) strong dissolution occurs. Such a fact is in agreement with the observations of Berger and Soutar (1970), who found better preservation of calcitic shells of planktonic foraminifers in the anaerobic parts of Santa Barbara basin (California) than in the adjacent oxygenated regions. Note that some strongly reduced sediments, in the Hellenic Trench for instance, show poor preservation of calcareous tests, in contrast to siliceous ones (Chamley, 1971).

In summary, the content of planktonic tests in most sapropels studied from Leg $42 \mathrm{~A}$ is much too small to 


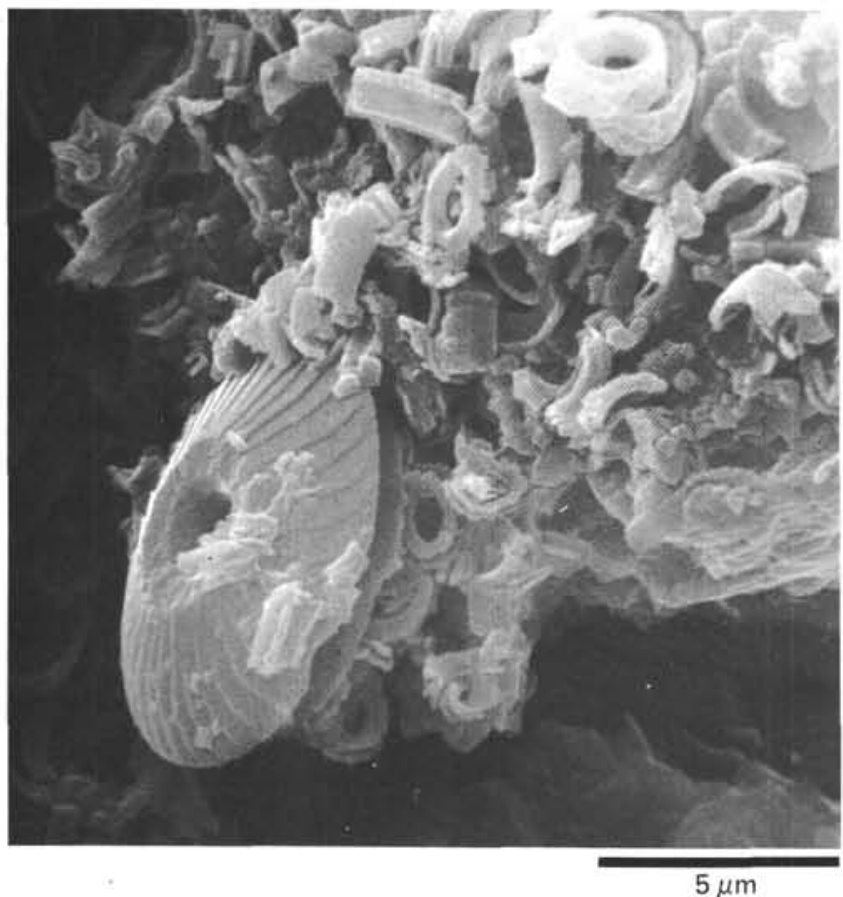

Figure 6. SEM photograph showing sediment mainly composed of coccoliths displaying minor dissolution; at lower left Cyclococcus Leptoporus. Site 374, Core 5, Section 3, $49-51 \mathrm{~cm}$, late Pleistocene; sapropel layer containing $5 \%$ to $16 \%$ organic carbon. $\times 4785$.

suggest a planktonic origin for their organic material. This suggests that other sources must have participated in the supply of organic matter. In fact, SEM micrographs show numerous organic fragments of unknown origin (Figures 9-10). Furthermore, the presence of plant debris with significant cellular structure provides strong evidence for a contribution of higher plant material to the amount of organic matter (Figure 11[A, $\mathrm{B}, \mathrm{C}]$ ). The distribution of $\mathrm{N}$-alkanes in sapropels of Pleistocene age goes even further to suggest that supply of organic matter from land-plant material is dominant (Wenzlow and Sigl, in preparation).

Thus, for some stagnation episodes, an increased influx of terrigenous organic detritus must be considered. This, on the other hand, contrasts with a calculation of river supplied organic material of less than $1 \%$ of that produced in the oceans (Bordovskiy, 1965). Emelyanov and Shimkus (1972) showed that $88 \%$ to $92 \%$ of the organic matter suspended in the Ionian Sea "is represented by organic detritus and by plankton undetected by net hauls" (p. 429). It is possible that the major part of this organic detritus originates from land plants. In a water body, poisoned by $\mathrm{H}_{2} \mathrm{~S}$, which rises close to the surface (say, within a few hundred meters of it, as is assumed for stagnation periods and is comparable to present-day conditions in the Black Sea), the bulk of the detritus might be able to reach the bottom and would be incorporated in the sediment. The uniform and fine dispersion of organic material, indicated by the distribution of iron sulfide particles, can be explained by the simultaneous deposition of

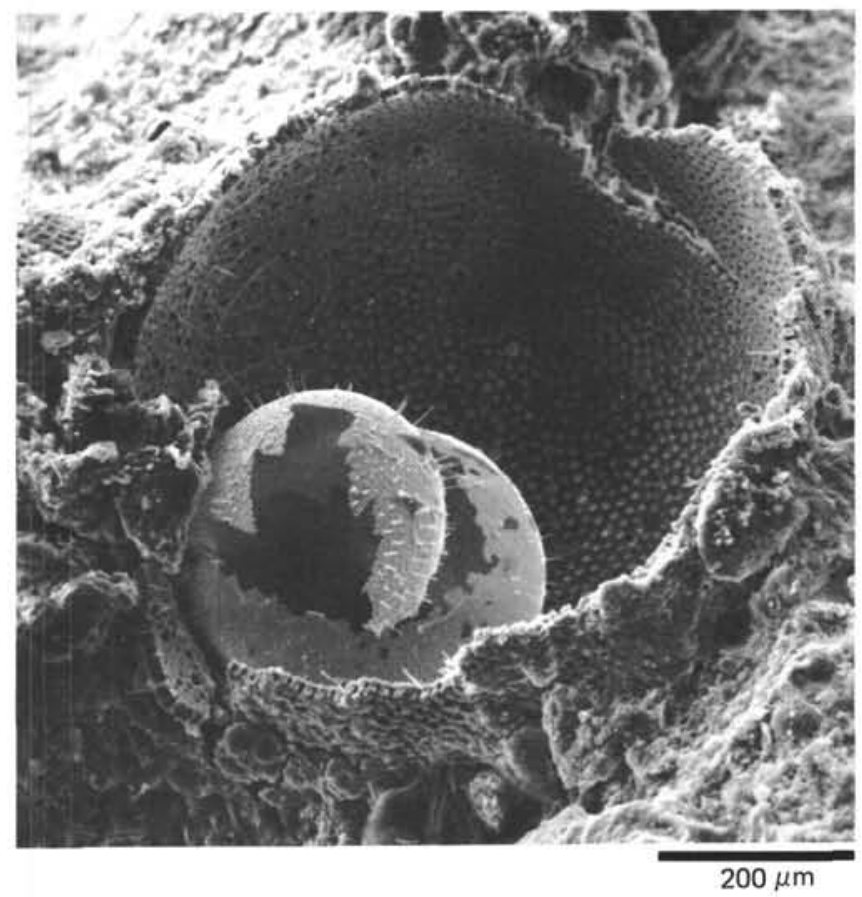

Figure 7. SEM photograph of broken test of planktonic foraminifer (Orbulina sp.) with faint dissolution patterns on its internal spheres. Site 374, Core 4, Section 2, 57.57.7 cm; Pleistocene, sapropel layer containing $2.4 \%$ organic carbon. $\times 100$.

particulate organic matter and clay minerals which are comparable in rate of descent through a liquid environment. Moreover, clayey material is able to absorb and protect organic particles during settling.

\section{Organic Carbon, Nitrogen, and Environment}

Nitrogen is one of the characteristic elements of living material: proteins, for example, on average contain $15 \%-19 \%$ of nitrogen. Similarly in organic carbon the nitrogen content has also a relation to the amount of organic matter. In addition, the nitrogen content of organic matter varies with the type of contributing organism, and furthermore, the ratio of organic carbon to organic nitrogen in the original material is also variable. Higher plants, for instance, Zostera, have high ratios of 15 to 20 , while planktonic material shows values around 6 (Bordovskiy, 1965). For marine sediments, the quantities of both organic carbon and nitrogen vary considerably because of these differences in source of organic matter and because of different decomposition during sedimentation. Moreover, diagenetic processes after sedimentation and burial subsequently alter the primary composition of the organic material. Under normal open marine conditions, organic matter is rapidly decomposed and becomes relatively depleted in nitrogen compounds which are less resistant. Once incorporated in the sediment, the decomposition of organic material will still continue. Thus, $\mathrm{C} / \mathrm{N}$ ratios of sediments must be interpreted with great care. 


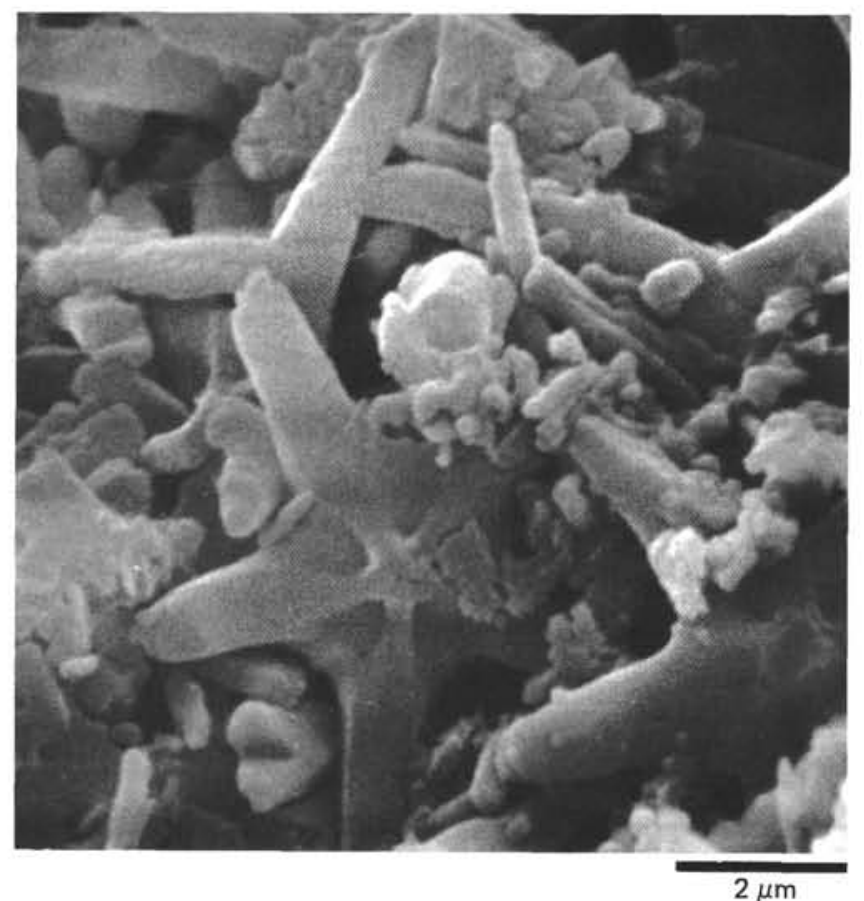

Figure 8. SEM photograph of sediment from a sapropel consisting mainly of plates of discoasters. Site 374, Core 6, Section 3, $64.5 \mathrm{~cm}$; late Pleistocene, sapropel layer containing $2.8 \%$ organic carbon. $\times 8700$.

Nevertheless, the plot of Figure 4-organic carbon versus total nitrogen-allows some degree of interpretation. Generally, the $\mathrm{C} / \mathrm{N}$ ratios given here are comparable with data of previous authors (Bordovskiy, 1965; Kreji-Graf, 1955; Seibold et al., 1958; and others). The arbitrary curve indicated in Figure 4 reflects the relation of $\mathrm{C} / \mathrm{N}$ ratios to varying content of organic carbon for samples from Sites 374,375 , and 376 . This relation is not linear. The obvious flattening of the curve to the left can be referred to "fixed and exchangeable" ammonia-nitrogen (Bremner, 1965) which, as well as organic nitrogen, is included in the amount of total nitrogen measured by the Kjeldahl method. As proved by Müller (1975), this mineralogically bound nitrogen is absorbed by clay minerals as smectite and increases with the amount of clay minerals in the sediments. Assuming that clay minerals are present in rather constant amounts within the sediments studied here, fixed nitrogen must relatively increase with decreasing organic carbon, thus causing lower $\mathrm{C} / \mathrm{N}$ ratios. It is to be expected that the curve would flatten the more the organic carbon values approach zero.

With increasing amounts of organic matter, the nitrogen content also increases. But, the more organic matter present, the more unprotected organic nitrogen will be decomposed. This leads to increasing $\mathrm{C} / \mathrm{N}$ ratios as indicated by the steepening of the plot line in Figure 4. At the opposite end of the curve, a further flattening is indicated, which reflects a relative increase of nitrogen again. This might be due to better preservation of nitrogen compounds which is assumed for a completely anaerobic sapropel facies (Potoniè, 1938; Kreji-Graf, 1955).
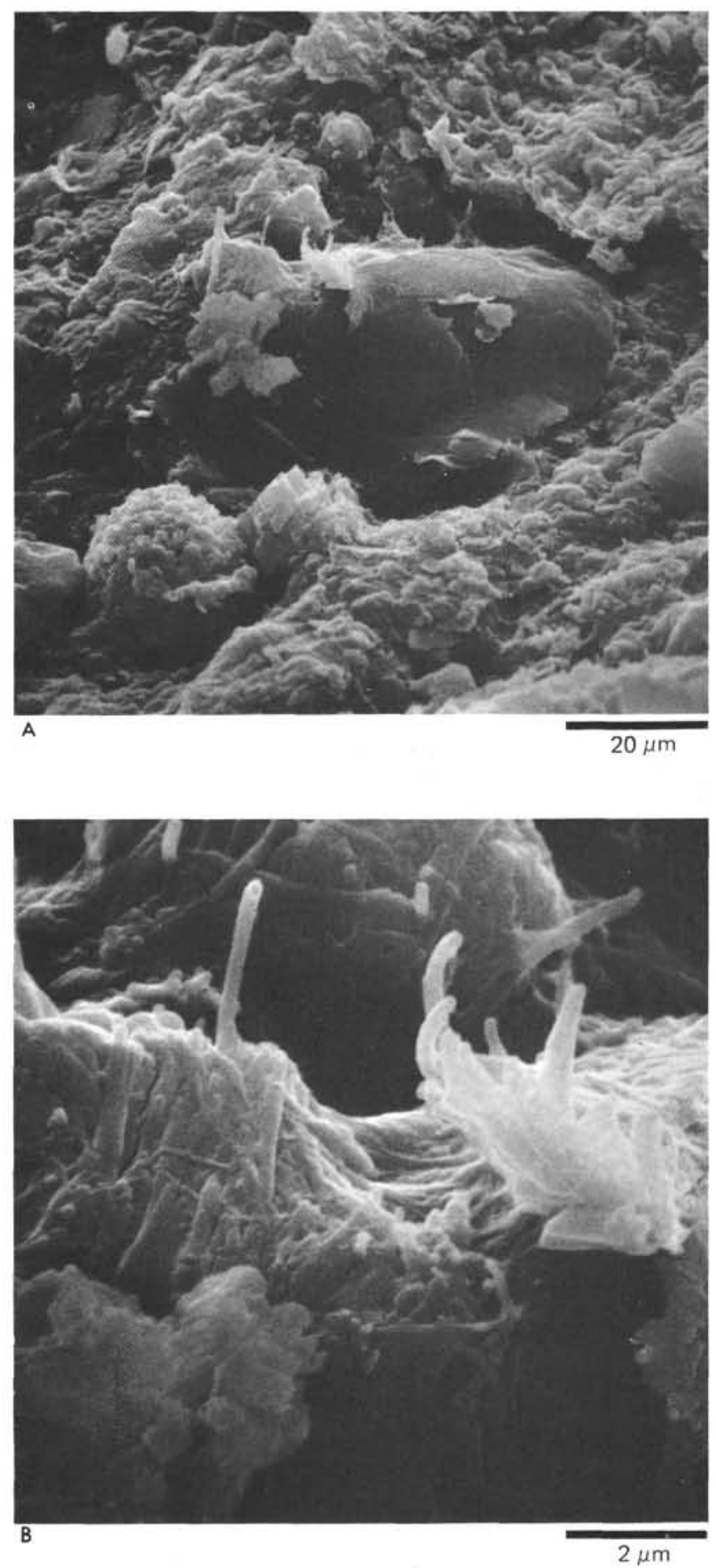

Figure 9. (A) SEM photograph of sapropel showing organic fragment (center), framboidal pyrite (lower left), and carbonate rhombs (lower center). Site 374, Core 5, Section 3, $50.3 \mathrm{~cm}$; compare Figure 6. $\times 1760 .(B)$ Detail of (A) center: fibrous structure of organic matter covering the surface of the organic fragment. $\times 8800$.

Site 374 samples show slight differences between Pleistocene and Pliocene sediments: on average, Pliocene samples have higher $\mathrm{C} / \mathrm{N}$ ratios than the Pleistocene ones. The plots of Miocene sapropels indicate further increases in the $\mathrm{C} / \mathrm{N}$ ratios. This could mean 


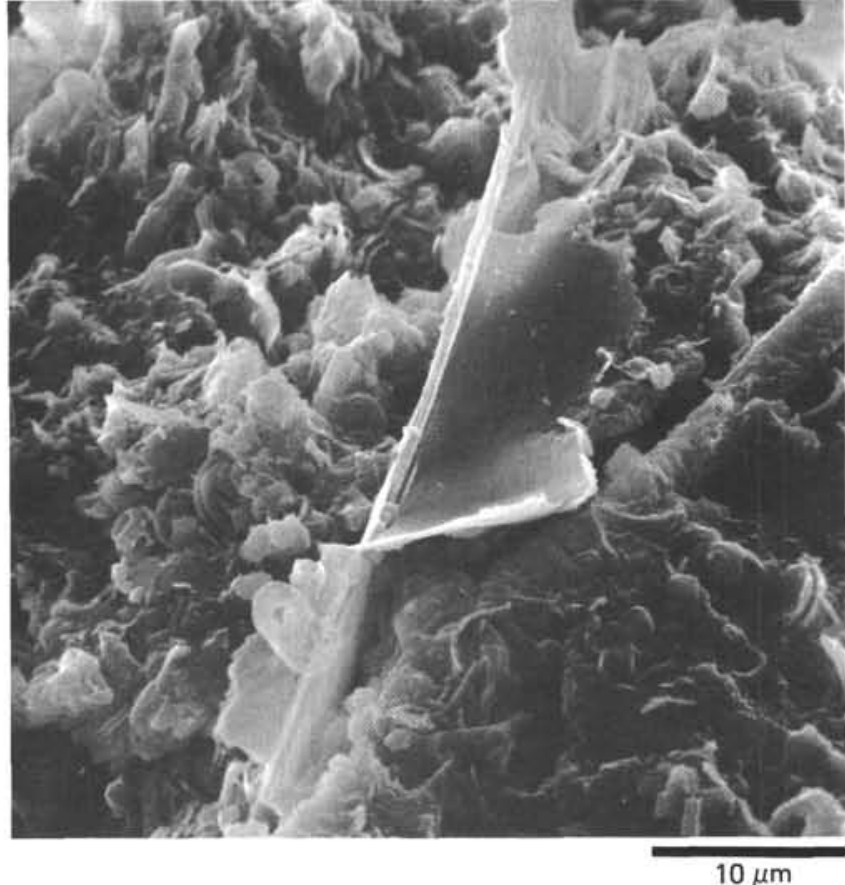

Figure 10. SEM photograph showing an organic fragment (plant debris?) embedded in a sediment rich in biogenic carbonate. Site 374, Core 5, Section 3, $53 \mathrm{~cm}$; compare Figure 6. × 1991 .

that the "geological aging affects the nitrogen content to a higher degree than the carbon content" (Arrhenius, 1950 , p. 16). An extremely high $\mathrm{C} / \mathrm{N}$ ratio (26.7) occurs in sample $17-1,72-75 \mathrm{~cm}$ of Site 374 . This sample shows abundant skeletons of diatoms (Figure 12) which might reflect an increased supply of relatively cold and less saline (fresh ?) water, possibly connected with a considerable supply of detrital plant material (see below). The determination of the diatoms might help to answer this question.

\section{Miocene and Pliocene-Pleistocene Sapropel Regimes}

Up to now, Miocene and Pliocene-Pleistocene sapropels have been discussed together, though very different environmental conditions might have been present during formation of both. This is mainly documented by differences in mineralogical content. Calcite is the dominant carbonate mineral in the Pliocene-Pleistocene sapropels of Sites 374 to 378 , and also in the Miocene sapropels of Site 376. It is mainly supplied to the sediment by tests of forminifers (Figure 7 ), coccoliths (Figure 6), and/or discoasters (Figure 8 ), which indicate more or less "open marine" conditions, at least for the water layers near the surface. On the other hand, the abundance of planktonic tests, as shown above, can change considerably within a given sapropel, and also it can be very different in different sapropels. Furthermore, the diversity of species of planktonic foraminifers is much restricted in some sapropel layers, while others show rather "normal" assemblages (Kidd et al., this volume).

These differences in planktonic production and in diversity of species during sapropel formation could have two main causes: first, the closeness of the stagnant $\mathrm{H}_{2} \mathrm{~S}$ containing deep water body to the surface might have differed, thus more or less limiting the living space of planktonic organisms; second, changes in the influx of cool and/or fresh water might have made conditions toxic to a greater or lesser degree for planktonic foraminifers.

At the tops of the sapropelic layer in Sample 2,CC and sapropel in Sample 4,CC (Site 374, Figure 1), the carbonate minerals aragonite and $\mathrm{Mg}$-calcite occur in considerable amounts. It seems likely that these mineralogic compounds were supplied by turbidites (Müller et al., this volume). Possibly the "turbiditic events" indicated here terminated these two relatively weak stagnant periods by supplying oxygenated water from the surface. The Mg-calcite in the Pleistocene sapropel sequences of Site 376 and in the sapropel layer of upper Miocene age in Site 375 (Sample 4-4, 40-62 cm) might have also originated in shallow water as shelf carbonates since these could also have been supplied by turbidites. This suggestion has support in that increased amounts of quartz, K-feldspar, and plagioclase are identified in these layers. In contrast, the Pliocene sapropel 6-4, 56-80 cm, of Site 375 shows a "normal" carbonate minerology which is characterized by significant amounts of detrital dolomite.

The dolomite of lowest Pliocene strata of Site 374 (Core 11, Figure 1) seems to result from diagenetic alteration of originally calcitic material. This is confirmed by the identification of numerous molds of foraminifers in SEM micrographs (Site 374 Report this volume). Also, the slight increase in organic carbon content in the normal background sediments might reflect increasingly restricted conditions during the formation of these strata.

In the Messinian of Site 374 (Cores 16-21), the dolomite is accompanied by gypsum which can be considered as a normal evaporitic product. ${ }^{5}$ The origin of the organic material in the Messinian sapropel layers is questionable. A significant marine planktonic contribution does not fit the picture of an evaporitic environment, moreover this source has been shown to be unlikely even for Pliocene-Pleistocene stagnation periods. Remains of marine planktonic organisms are rare in these layers and are commonly represented by skeletons of diatoms (Figure 12). Organic structures which possibly were built by algae (Figure 13[A, B, C]) might suggest the occasional presence of oxygen, while high $\mathrm{C} / \mathrm{N}$ ratios indicate a strong contribution of land plant material. A terrigenous influence, either wind borne or river-supplied, is further documented by pollen analysis (Bertolani-Marchetti and Accorsi, this volume). It is possible that the sapropels of these evaporitic strata were formed in a shallow (lagoonal ?) saline basin with rather stagnant abiotic condition, but occasionally "refreshed" by influxes of marine or fresh water which might cause algal blooms and increase supply of organic material from land.

\footnotetext{
5 Editors Note: The reader is reminded that the definition of sapropels as adopted in the preceding contribution (Kidd et al., this volume) would not encompass organic carbon-rich sediments encountered within the Messinian evaporitic sequence.
} 


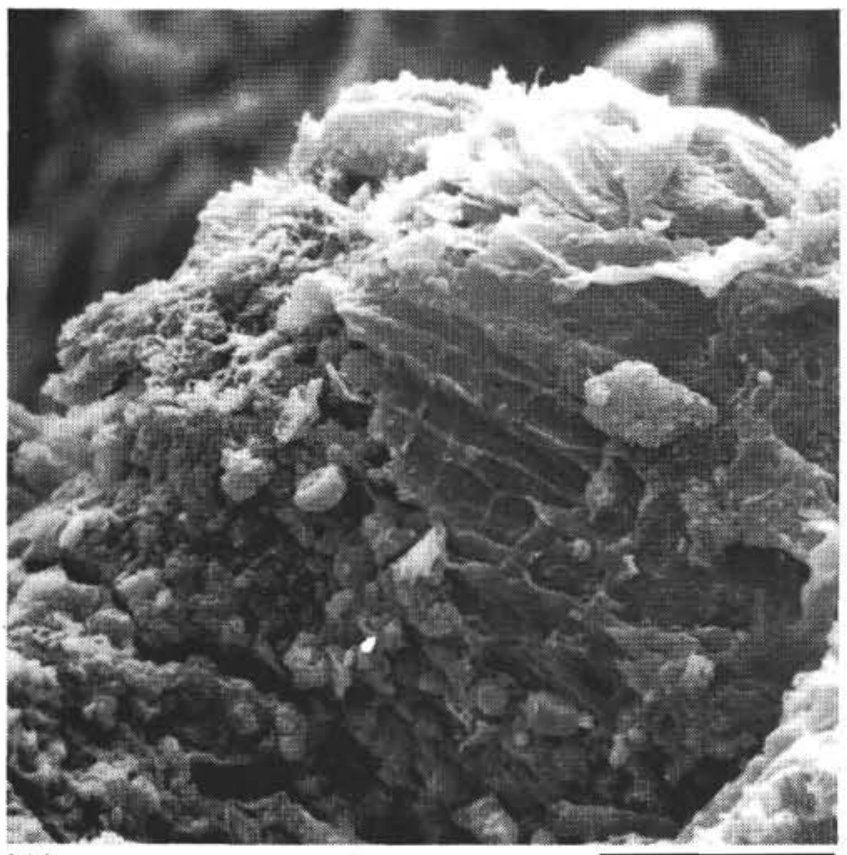

(A)
$50 \mu \mathrm{m}$

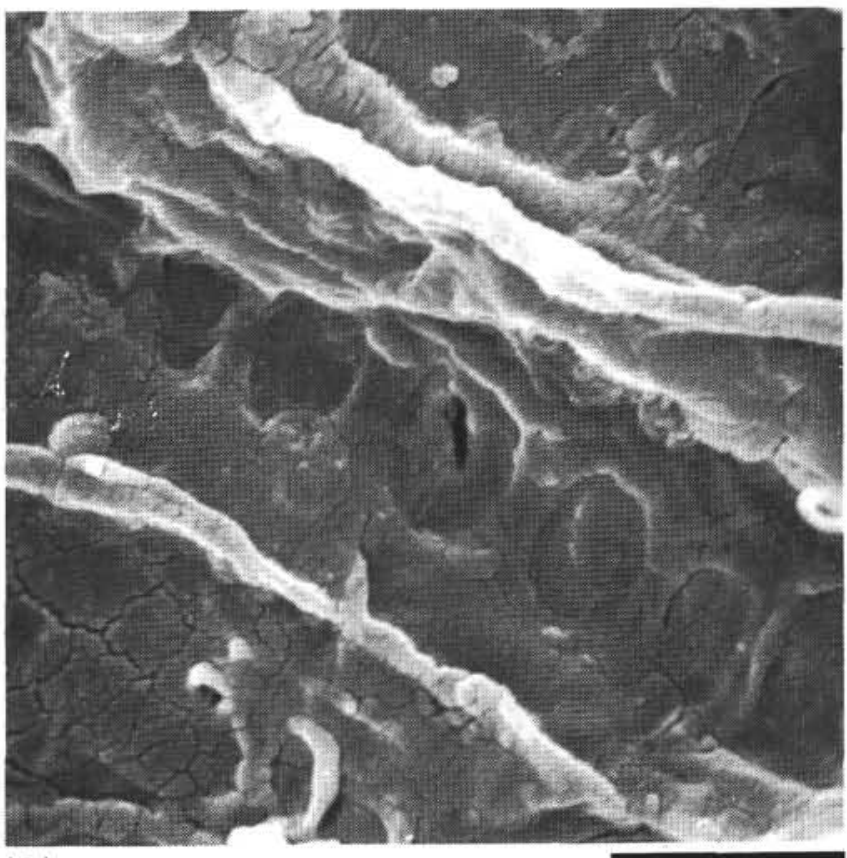

(B)

$5 \mu \mathrm{m}$

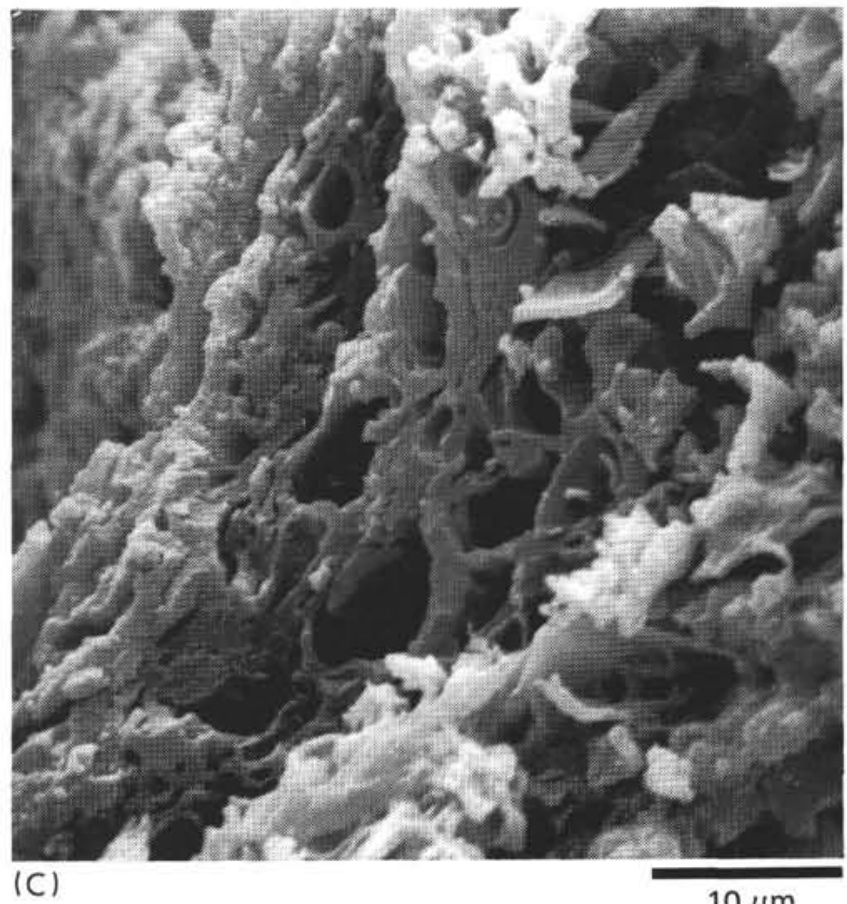

$10 \mu \mathrm{m}$

Figure 11. (A) SEM photograph of sapropelic sediment $(0.6 \%$ org. C) with a plant fragment embedded in marlstone, Site 376 (Florence Rise, Levantine Sea), Core 12, Section 1, 22-28 cm, late Miocene (Messinian). x 473. (B) Detail of (A); the ultrastructure is typical of a wood plant (vessels, cellular structures, stigmation). $\times 4730$. (C) Further detail of (A); crossfracture of a fragment of a wood plant (double-layered walls, cellular structure, vessels in cross section). $\mathrm{x} 1892$. 


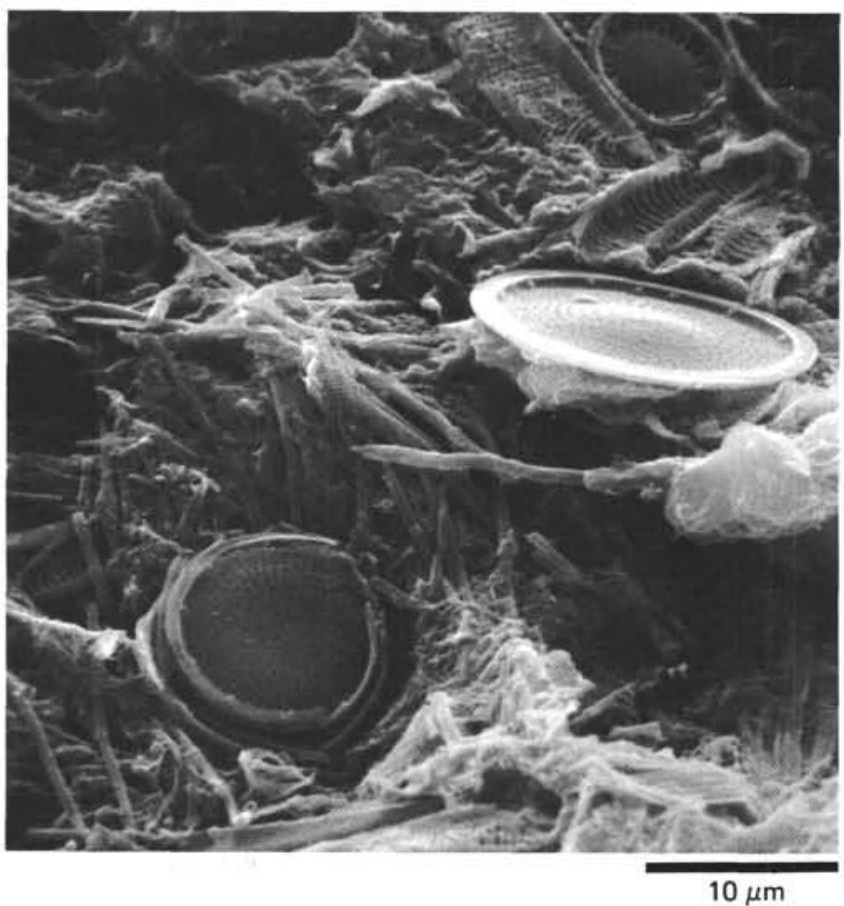

Figure 12. SEM photograph of a sapropel composed mainly of diatoms; the organic matter is represented partly by fibers and partly by thin films covering the siliceous fragments. Site 374, Core 17, Section 1, 62$63 \mathrm{~cm}$; Messinian; sapropel $(2.1 \%$ org. C). $\times 1914$.

\section{Occurrence of Gypsum in Reducing Sediments}

A problem arises in that gypsum is commonly associated with sapropels. For those of the Quaternary layers, some authors have thought the gypsum to be an artifact formed during the storage of cores by oxidation of sulfides to sulfates and reaction of interstitial calcium to gypsum. Our own experience in part supports this assumption, although some indications of primary gypsum remain. Robert and Chamley (1974) and Cita et al. (in press) argue for a primary origin. While the availability of calcium in sediments rich in organic carbon is not a problem (Berner, 1968), the coexistence of sulfate and sulfide precipitation within a given layer is not easy to explain.

In the Messinian evaporitic sapropels of Site 374, gypsum (and anhydrite) are abundant, although $\mathrm{Fe}$ sulfides which are typical of organic sediments, are also present. This proves that contemporary precipitation of sulfate and sulfide is possible.

\section{Clay Mineralogy and Organic Matter Content}

Differences in the clay mineralogy between sapropelic and normal sediments have been described by several authors. In upper Pleistocene and Holocene sediments, Chamley (1971) noted a decrease of the smaller and more expandable minerals smectite, open illite, mixed-layers, especially in the more stagnant areas of the Mediterranean, for example, the Hellenic Trench. He referred this decrease to the degradation or destruction of the more vulnerable minerals under the influence of organic matter contained in sapropels. Nesteroff (1973) observed the opening of illite reflections and the development of mixed-layers in cores of Leg 13 and related the degradation to the organic carbon content. Analogous results have been obtained by Robert (1974) and Cita et al. (in press) from the study of a long piston core from the Mediterranean ridge (Ionian Sea); here, the chlorite increases within the sapropels in comparison to the adjacent normal sediments. From a detailed study of DSDP Site 125 (Leg 13, Mediterranean ridge), Chamley (in press) discussed the formation of mixed-layer clay minerals during the degradation of smectite in the presence of organic matter. In all these cases the alterations of the clay minerals are referred to authigenic diagenetic modification and not to primary mineralogical differences in the supplied sediment.

The study of Tortonian, Pliocene, and Pleistocene sapropels of Leg 42A (Figures 14-17) confirmed the results from the previous leg: sediments rich in organic carbon are unfavorable sites for preservation of detrital clay. An exception are the Messinian strata which show no difference in their clay mineralogy to their associated normal sediments. Based on these results and on analyses of piston-cored sediments, we can summarize the problem of alteration of clay minerals in the sapropelic environment in the general diagram (Figure 18).

\section{Weathering of Clay Minerals in Sapropels}

All clay minerals brought into the sea may be weathered by an euxinic environment, perhaps with the exception of kaolinite. The intensity and rapidity of alterations, however, differs considerably for the different clay minerals. The succession of increasing resistance against degradation is attapulgite $\gtrless$ smectite $\gtrless$ chlorite $\gtrless$ illite $\gtrless$ kaolinite.

When attapulgite content is appreciable, the other clay minerals seem to be to some extent protected from degradation, at least until most of the attapulgite is destroyed. When attapulgite is rare or absent, smectite and the associated mixed-layer types GEQL"complexe gonflant") are affected first. A good example of such a sequence is provided in the Pliocene sapropels of Site 374: the abundant but fragile attapulgite is destroyed and thus the smectite was shielded from alteration. In the Pleistocene sapropels the attapulgite is rare so the smectite is considerably weathered. The different minerals thus build successive barriers against degradation. Similar processes seem to occur in well-drained soils during weathering (Millot, 1964).

A rather marked relationship is obvious between the content of organic carbon and the intensity of degradation (see Figures 1 to 3 ): the detrital clay minerals are more degraded the more the content of organic carbon increases. Experimental studies by Huang and Keller (1971, 1972a, b) showed the influence of organic acids on the degradation of silicates. It is likely that bacteria control these mechanisms. 


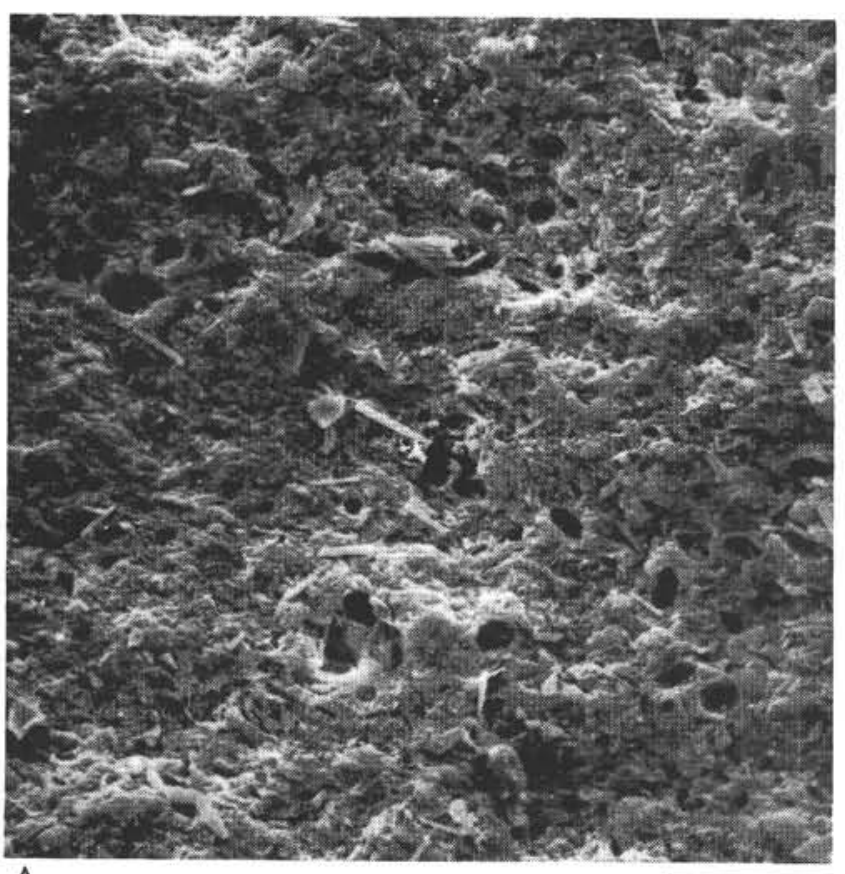

A

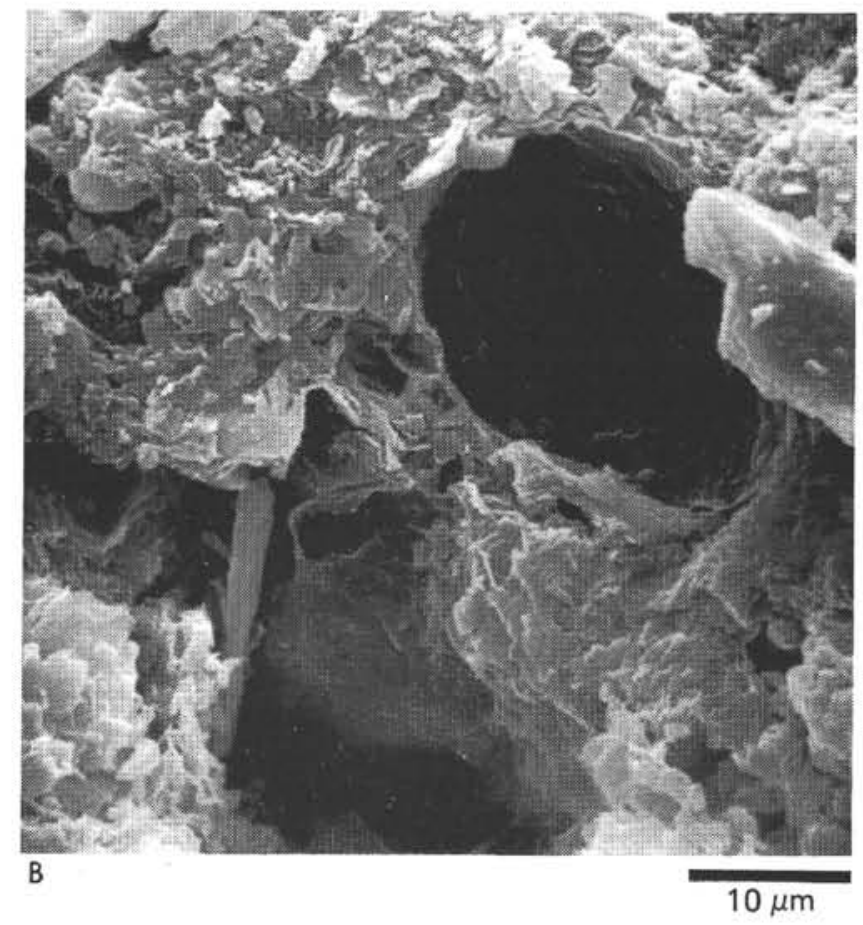

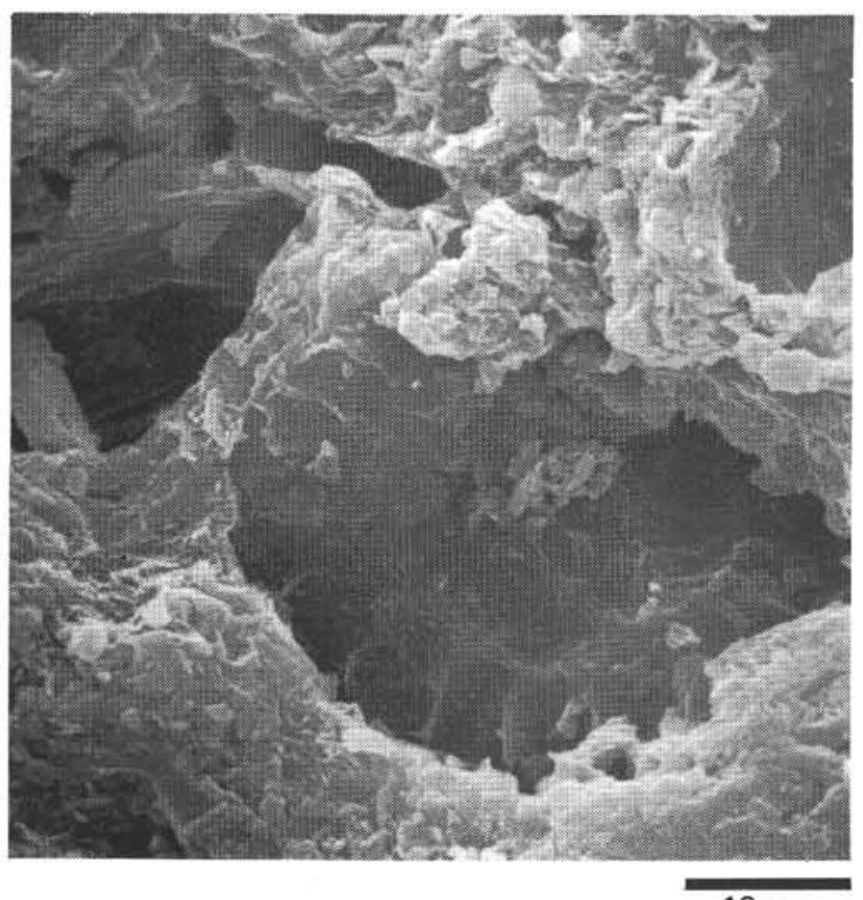

$10 \mu \mathrm{m}$

Figure 13. (A) SEM photograph showing the surface of a fracture in laminated gypsum rich in organic matter (=sapropel; 5.2\% org. C), and displaying empty molds of probable algal origin. Site 374, Core 20, Section 1, 24-25 cm; Messinian $\times 162$. (B) Detail of Figure 13a; thin films of organic matter lining the walls of the molds $\times 1620$. (C) Further detail of Figure 13a; empty mold lined by a film of organic matter. The structure here appears to have been built by coccoid algae $\times 162$.

\section{Transitional Minerals in Sapropels}

The first stages of alteration generally result in formation of mixed-layer clay minerals which may belong to the following irregular forms: illite-vermiculite, illite-smectite, chlorite-vermiculite, chlorite-smectite. Smectite, then chlorite, and finally illite are con- verted to these transitional minerals during their disorganization. If the organic influence is very strong, the degradation is replaced by destruction and the mixedlayer types are not developed (Chamley, 1971).

Another form of transition seems to occur as an increase in chlorite when the alteration under organic influence is weak or moderate, that is lower than that 


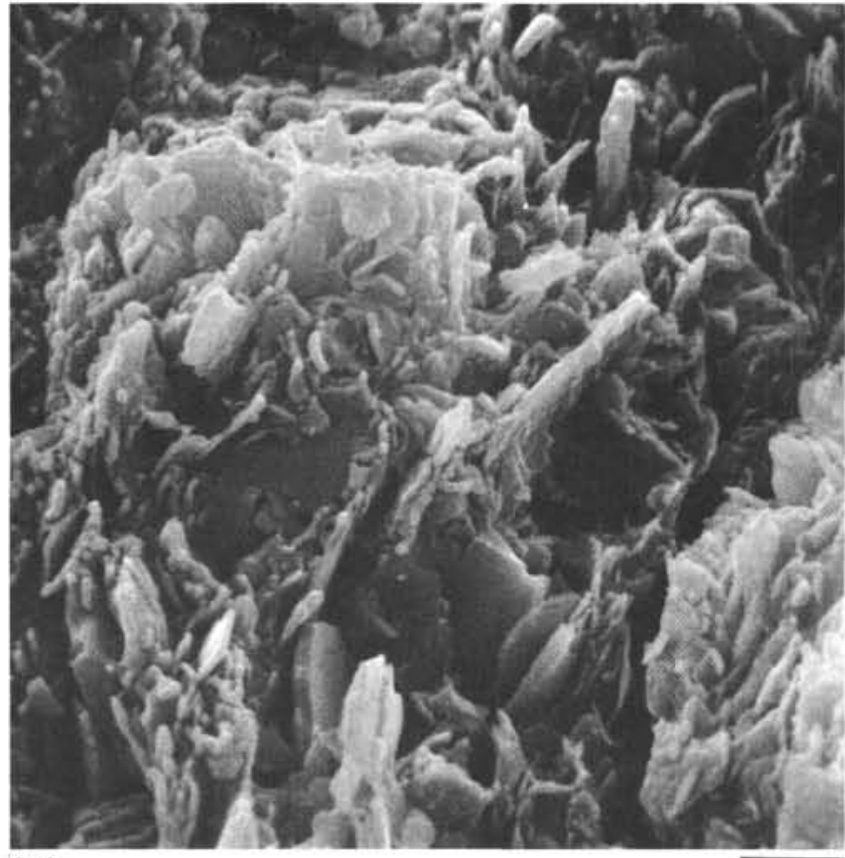

(A)

$2 \mu \mathrm{m}$

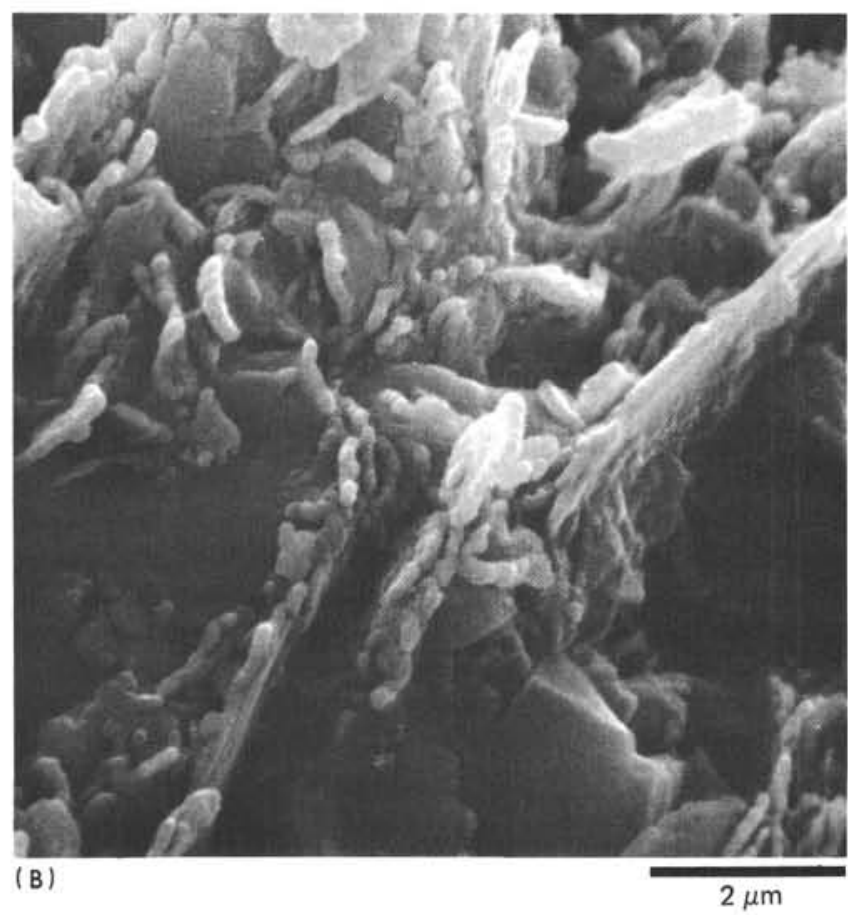

Figure 14. (A) SEM photograph of the surface of a cross/ fracture in a sapropel: a bedding plane runs diagonally from upper right to lower left. Components mainly are carbonate fragments and clay minerals. Site 374, Core 3, Section 1, $141 \mathrm{~cm}$; Pleistocene. X 5046. (B) Detail of (A); the edges of the clay minerals show a knobby, bulbous or vermiform structure, probably caused by synsedimentary alteration. $\times 10,092$.

necessary to produce the greatest development of mixed-layer clay minerals (Sites 125, 376, and locally in Site 374). This phenomenon might be due to a complexation effect in the smectite caused by the

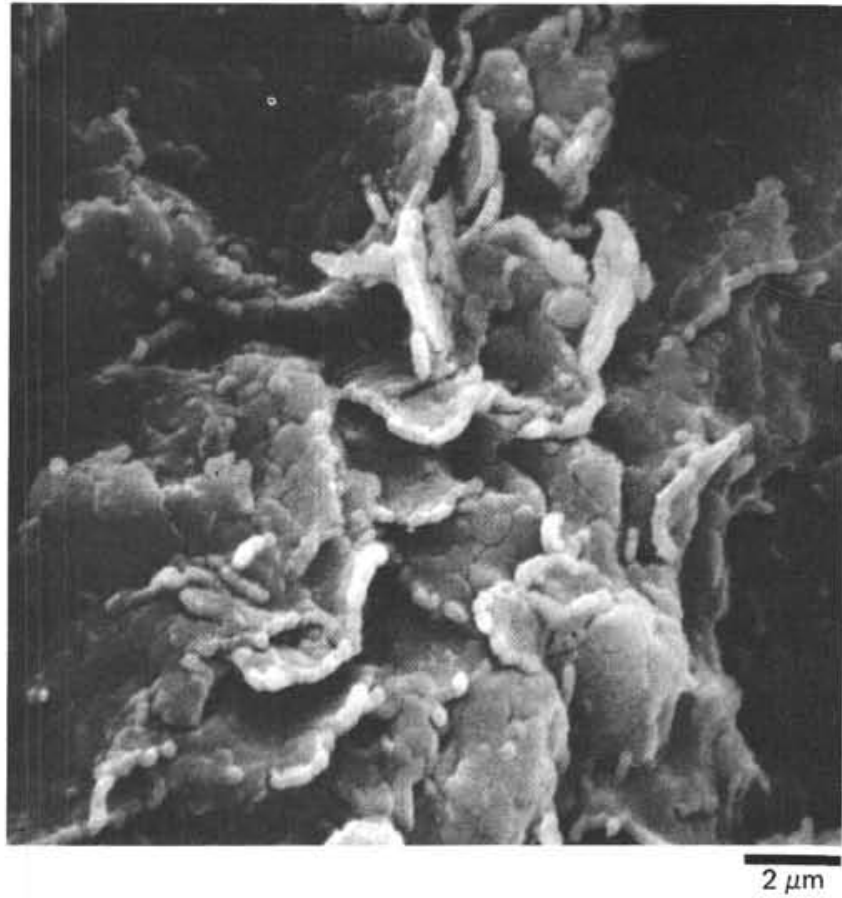

Figure 15. SEM photograph of sapropelic sediment $1.4 \%$ org. C) in which the clay minerals show knobby edges and other alteration patterns or cracks. Site 374, Core 9, Section 1, $150 \mathrm{~cm}$; early Pliocene. $\times 4611$.

organic matter being absorbed in the clay interlayers, bringing about an apparent "chloritization."' Such processes have been experimentally demonstrated by Heller-Kallai et al. (1973) from molecular amines and other organic components, and they could take place in nature in the sapropels. Some support for this argument is provided by mineralogic study of different granulometric fractions of sapropels: sand-size and exclusively detrital chlorite occurs in normal abundance in the sapropels in which clay-size chlorite is abnormally abundant. On the other hand, the above may be a premature stage in the geochemical dynamics of a stagnant environment, inconsistent with strong conditions of hydrolysis.

\section{Geographic and Stratigraphic Distribution of Degradation in the Clay Minerals of Mediterranean Sapropels}

The composition of the clay fraction inherited from Mediterranean continental areas has an influence on the type of alteration which occurs during stagnant periods. Off North African coasts, attapulgite was deposited in abundance in Pliocene times (Sites 125, 374) (Chamley, 1975; Mélières et al., this volume). This fragile mineral was destroyed at first and thus protected other minerals from degradation (Site 374). In Pleistocene sediments off Sicily and Asia Minor, smectite occurs in abundance and shows the greatest degradation (Sites 374, 375, 376). Near Greece and Crete, illite and chlorite are present in significant amounts as well as smectite, and both show degradation (Leg 13, Sites 125, 127, 128; Leg 42A, Sites 377, 378; Charcot Medor cores; Charcot Polymede cores). 


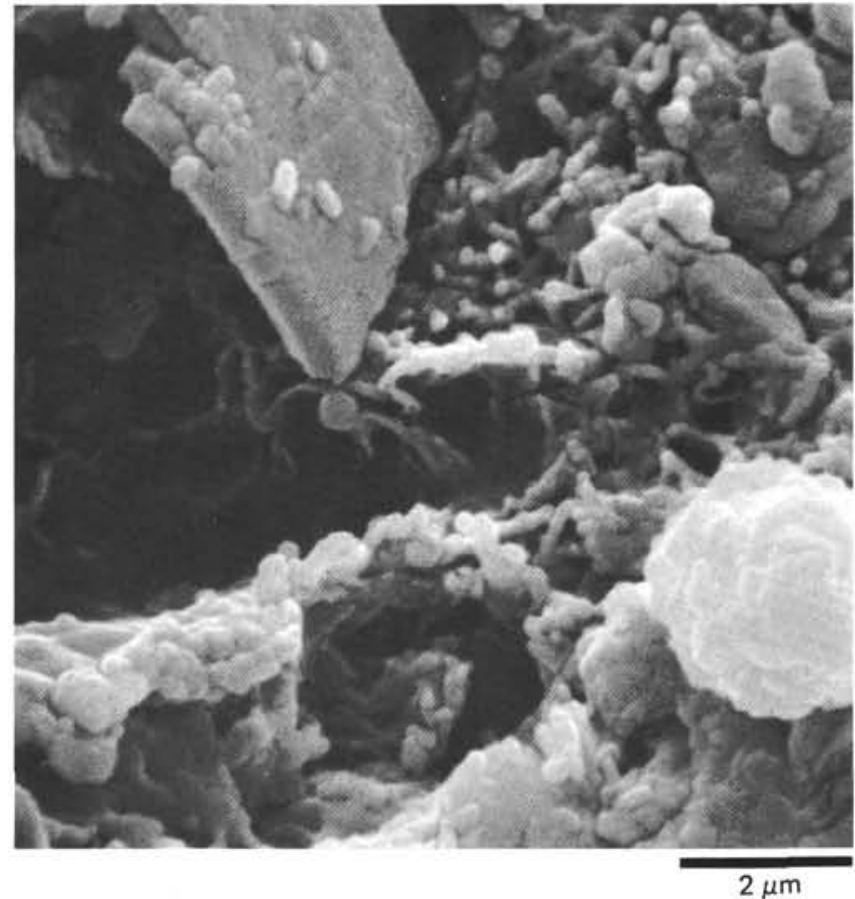

Figure 16. SEM photograph of laminated gypsum with embedded clay minerals which show a knobby and veriform appearance, probably due to synsedimentary alteration; note the framboidal pyrite in the lower $25 \mathrm{~cm}$; sapropel (5.2\% org. C) Messinian; compare Figure $13(\mathrm{~A}) . \times 8700$.

The location of the piston coring and drilling into the ancient sapropelic areas also has an effect on the alteration type encountered. It appears that the inherited minerals are less weathered if the zone is located at the periphery of the sapropelic area, where water exchange is favored and the organic matter less abundant. This is most apparent on the edge of the Messina Abyssal Plain (Charcot Polymede II, Core KS 03). Also a similar decrease of stagnant conditions may be brought about by the turbiditic events within the stagnant periods (Nesteroff, 1973).

Another important feature of the degradation distributions is their relationship to bathymetry. If the area is flat and deep, stagnation is favored and the alteration is marked, as in the Hellenic Trench (Cores 2M067, 3M067, Charcot Medor where direct destruction of simple minerals without transitional forms has occurred. This also occurs to some degree in the North Cretan basin (Site 376) in lower Pleistocene sediments. On the other hand, in cores from submarine elevations or shelf zones, degradation is moderate (Sites 125, 377; Mediterranean ridge) or weak (Sites 376, 376; Florence rise; Jean Charcot Cores 25M067, 44M067, from north of Crete). This is certainly due to the intervention of currents being common causing the development of irregular mixed-layer clay minerals. Furthermore, sapropelitic zones high on the basin peripheries show simultaneous growth of sulfur and sulfates from the $\mathrm{H}_{2} \mathrm{~S}$ produced by bacterial activity (Robert and Chamley, 1974; Cita et al., in press).
In the sapropels themselves the alteration often increases towards the base. This phenomenon, which is not evident when the average degradation is weak (Sites 375, 376), is significant when stagnant conditions were strong (Sites 374 , locally at 378 , and in Core Polymede II KS09). Such a trend which affects the clays but also some other sedimentary components (Robert, 1974) leads one to the conclusion that the alteration chiefly occurred at the water-sediment interface, that no diagenetic modification happened after burial, and that the stagnant conditions often were more severe at the beginning of the sapropelic phases than at the end.

The degradation intensity is strictly independent of depth of burial and the age of the sapropels. There exist sapropels with strongly degraded clay assemblages which lie above others showing little alteration (Site 374, Cores 5, 6; Site 376, Cores 1 and -6; Site 378 , Cores 1,3). This fact constitutes a further argument against the occurrence of burial diagenetic effects in organic carbon-rich sediments.

\section{SUMMARY}

To summarize we propose the following succession of stages of clay mineral alteration in sapropels:

Stage 1.2Very little alteration: moderate degradation of attapulgite, little development of smectitic mixedlayers.

Stage 2. Weak alteration: strong degradation of attapulgite; moderate degradation of smectite resulting in the developed of irregular mixed-layer types (smectite-chlorite, smectite-illite); possible development of "complexation" chlorite.

Stage 3. Moderate alteration: destruction of attapulgite; greatest development of irregular mixed-layer types derived from the degradation of smectite and in part of chlorite and illite (illite-vermiculite, illitesmectite, chlorite-vermiculite, chorite-smectite).

Stage 4. Strong alteration: destruction of the transitional minerals (possible complexation chlorite, irregular mixed-layers) as well as most of the smectite; strong degradation of the less well crystallized primary illite and chlorite particles.

Stage 5. Very strong alteration: destruction of the whole clayey fraction, except for large-size chlorite particles, the mica-illites (which would nevertheless be corroded on their periphery) and perhaps kaolinite.

The alteration intensity depends on the total content of organic matter. Probably specific organic components determine how strong is the mineralogic degradation. Future studies must focus on the precise trends in the mineral hydrolysis as well as on the characteristics of the bacterial control.

\section{ACKNOWLEDGMENTS}

The investigations on the Leg $42 \mathrm{~A}$ material were supported by the Deutsche Forschungsgemeinschaft (Germany) and Grant $75 / 5155$ of the C.N.E.X.O. (France). For discussion and critical review, we are gratefully indebted to $\mathrm{M}$. B. Cita, W. Hieke, and R. B. Kidd. 


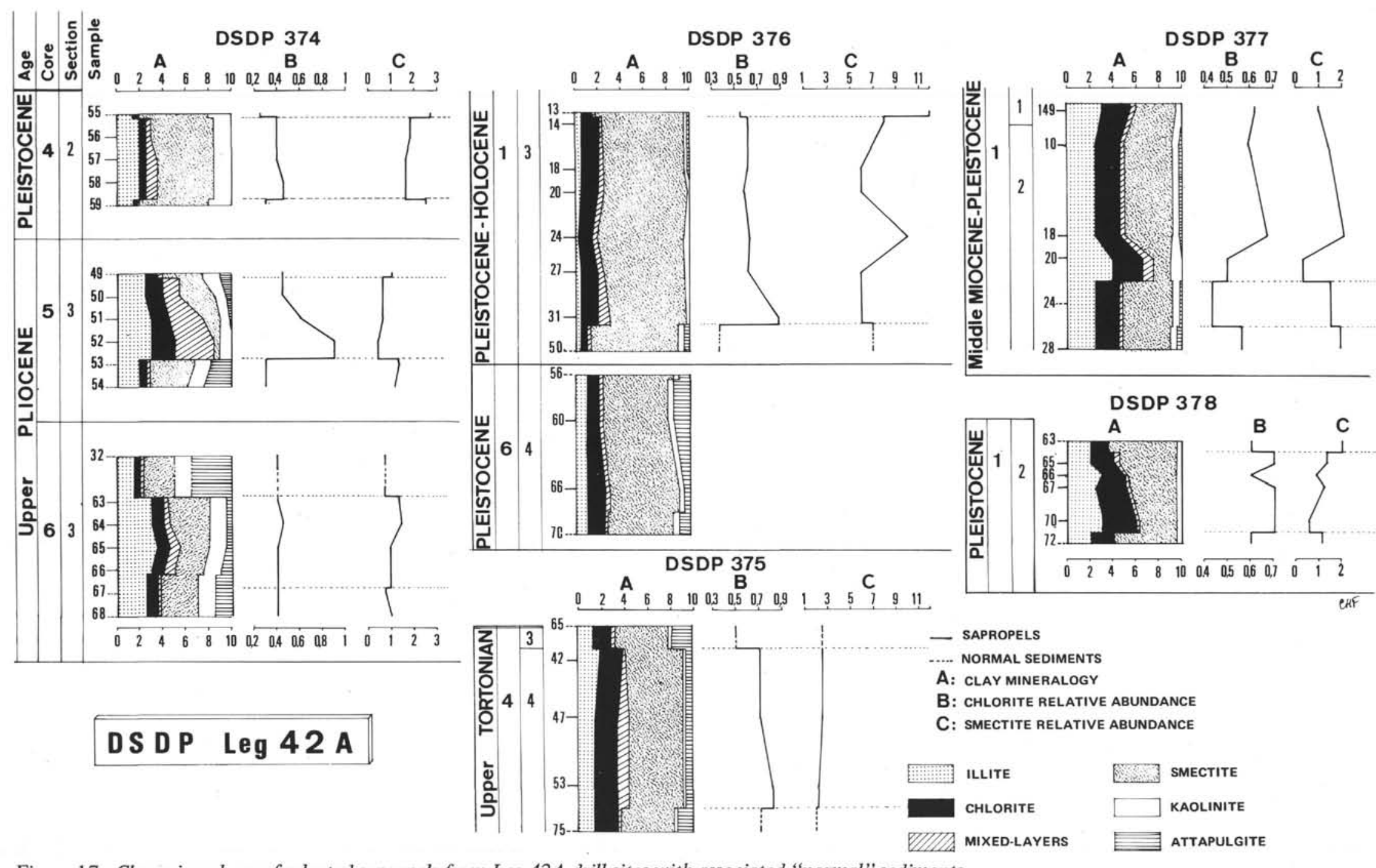

Figure 17. Clay mineralogy of selected sapropels from Leg $42 \mathrm{~A}$ drill sites with associated "normal" sediments. 


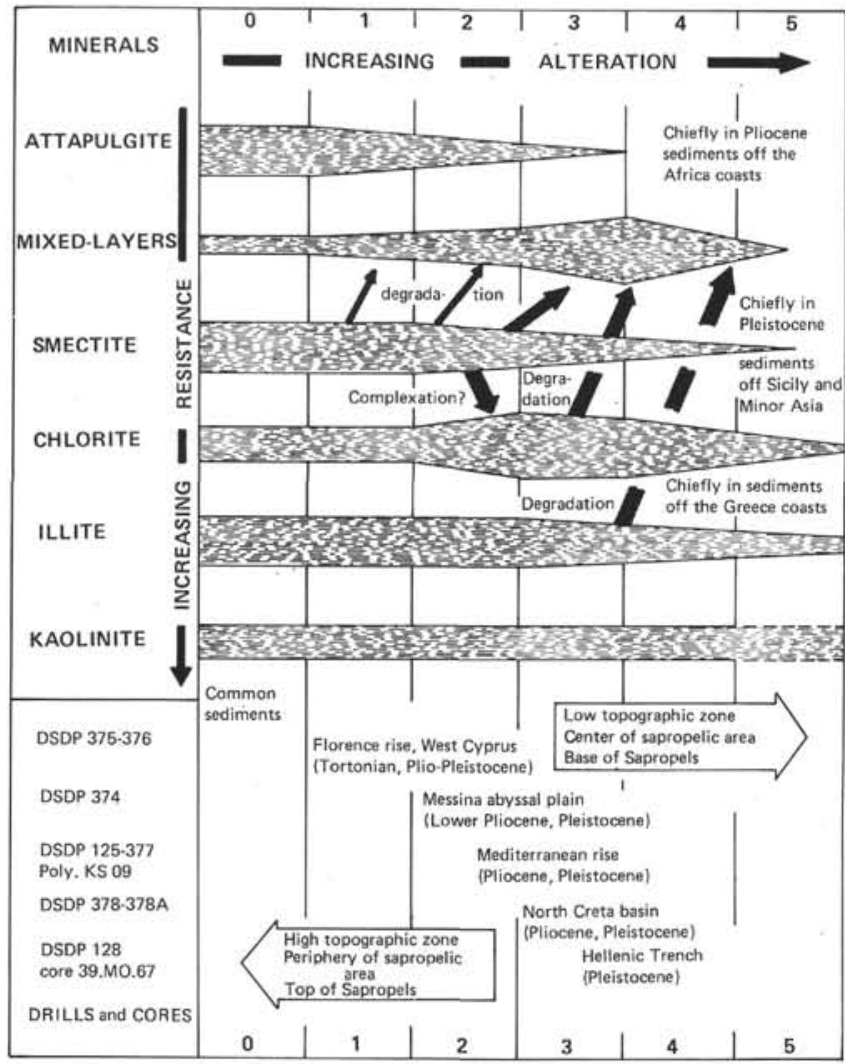

Figure 18. Clay mineral diagenesis in Pliocene-Pleistocene sapropelic environments of the eastern Mediterranean: interpretation of the results of Glomar Challenger and Jean Charcot cruises.

\section{REFERENCES}

Arrhenius, G., 1950. Carbon and nitrogen in subaquatic sediments: Geochem. Cosmochim. Acta, v. 1, p. 15-21

Berger, W. H. and Soutar, A., 1970. Preservation of plankton shells in an anaerobic basin off California: Geol. Soc. Am. Bull., v. 81 , p. $257-282$.

Berner, R. A., 1968. Calcium carbonate concretions formed by the decomposition of organic matter: Science, v. 159, p. 195-197.

1970. Sedimentary pyrite formation: Am. Jr. Sci., v. 268 , p. $1-23$.

Bordovskiy, O. K., 1965. Accumulation and transformation of organic substances in marine sediments: Marine Geol. v. 3, p. 3-114.

Bradley, W. H., 1938. Mediterranean sediments and Pleistocene sea levels: Science, v. 88 , p. $376-379$

Bremner, J. M., 1965. Inorganic forms of nitrogen. In Black, C. A. (Ed.), Methods of soil analysis: Part 2, Agronomy 9, p. 1179-1237.

Brongersma-Sanders, M., 1957. Mass mortality in the sea. In Hedgpeth, P. W. (Ed.), Treatise on marine ecology and paleoecology, Part 1: Mem. Geol. Soc. Am., v. 67, p. 9411010.

Chamley, H., 1971. Recherches sur la sédimentation argileuse en Méditerranée: Sci. Géol., Mém. 35, Strasbourg, p. 225.

in press. Sédimentation argileuse en mer Ionienne au Plio-Pléistocéne d'après l'étude des forages 125 DSDP: Soc. Géol. France Bull.
Cita, M. B., 1973. Inventory of biostratigraphical findings and problems. In Ryan, W. B. F., Hsü, K. J., et al., Initial Reports of the Deep Sea Drilling Project, Volume 13: Washington (U. S. Government Printing Office), p. 10451073.

Cita, M. B., Chierica, M. A., et al., 1973. The Quaternary record in the Tyrrhenian and Ionian basins of the Mediterranean Sea. In Ryan, W. B. F., Hsü, K. J., et al., Initial Reports of the Deep Sea Drilling Project, Volume 13: Washington (U. S. Government Printing Office), p. 12631339.

Cita, M. B., Vergnaud-Grazzini, C., Robert, C., Chamley, H., Ciaranfi, N., and d'Onofrio, S., in press. Paleoclimatic record of a long deep-sea core from the eastern Mediterranean: Quat. Res.

Emelyanov, E. M. and Shimkus, K. M., 1972. Suspended matter in the Mediterranean Sea. In Stanley, D. J. (Ed.), The Mediterranean Sea: Strasbourg, Virginia (Dowden, Hutchinson and Ross), p. 417-439.

Fabricuis, F., 1961. Die Strukturen des "Rogenpyrits", (Kössener Schichten, Rät) als Beitrag zum Problem der “vererzten Bakterien". Geol. Rundschau, v. 51, p. 647657.

Goddard, E. N., 1963. Rock color chart. Geol. Soc. Am., Tech. Publ.

Heller-Kallai, L., Yariv, S., and Riemer, M., 1973. The formation of hydroxy interlayers in smectites under the influence of organic bases: Clay Minerals, v. 10, p. 35-40.

Huang, W. H. and Keller, W. D., 1971. Dissolution of clay minerals in dilute organic acids at room temperature: Am. Mineralogist, V. 56, p. 1082-1095.

1972a. Kinetics and mechanism of dissolution of fifthian illite in two complexing organic acids. Internat. Clay Conf., Proc. 1972, p. 321-331.

$1972 \mathrm{~b}$. Organic acids as agents of chemical weathering of silicate minerals: Nature Phys. Sci., v. 239, p. 149151.

Javor, B. J. and Mountjoy, E. W., 1976. Late Proterozoic microbiota of the Miette Group, southern British Columbia: Geology; p. 111-119.

Kreji-Graf, K., 1955. Zur geochemie der Erdölentstehung: Erdöl and Kohle, v. 8, p. 393-401.

Kullenberg, B., 1952. On the salinity of the water contained in marine sediments: Goteb. Akad. Vet. Vitt-Somhales, Handl. Sjatte Fol., ser. 8, v. 6, p. 3-37.

McCoy, F. W., 1974. Late Quaternary sedimentation in the eastern Mediterranean Sea: $\mathrm{Ph}$. D. Thesis, Harvard University, Cambridge, Massachusetts.

Miller, A. R., 1972. Speculations concerning bottom circulation in the Mediterranean Sea. In Stanley, D. J. (Ed.), The Mediterranean Sea: Strasbourg, Virginia (Dowden, Hutchison and Ross), p. 37-42.

Millot, G., 1964. Géologie des Argiles: Paris, (Masson) p. 499.

Müller, P., 1975. Zur diagenese stickstoff-haltiger substanzen in marinen sedimenten unter oxydierenden und reduzierenden Bedingungen: Dissertation, Universität Kiel, Germany, p. 180.

Nesteroff, W. D., 1973. Petrography and mineralogy of sapropels. In Ryan, W.B.F., Hsü, K. J., et al., Initial Reports of the Deep Sea Drilling Project, Volume 13; Washington (U. S. Government Printing Office), p. 713720. 
Olausson, E., 1961. Studies of deep-sea cores: Rept: Swedish Deep-Sea Exped., v. 8, p. 337-391.

Potoniè, R., 1937. Die nomenklature der unterwasser-ablagerungen: Jahrb. Preuss. Geol. Landesanstalt, v. 58, p. 426428.

Robert, C., 1974. Contribution à l'étude de la sédimentation argileuse en Méditerranée orientale. Thèse 3ème cycle, Aix-Marseille II, dact., p. 86.

Robert, C. and Chamley, H., 1974. Gypse et sapropels profonds de Méditerranée orientale; C. R. Acad. Sci., Paris, Ser. D, v. 278 , p. 843-846.

Ryan, W. B. F., 1972. Stratigraphy of late Quaternary sediments in the eastern Mediterranean. In Stanley, D. J., (Ed.), The Mediterranean Sea: Strasbourg, Virginia (Dowden, Hutchison and Ross), p. 419-176.

Ryan, W. B. F., Hsü, K. J., et al., 1973. Initial Reports of the Deep Sea Drilling Project, Volume 13: Washington (U.S. Government Printing Office).
Seibold, E., Müller, G., and Fesser, H., 1958. Chemische Untersuchungen eines Sapropels aus der mittleren Adria: Erdöl and Kohle, v. 5, p. 296-300. in preparation. Sapropel(ic) layers in meteor-cores from the eastern Mediterranean.

Sigl, W. and Müller, J., in press. Identification and correlation of stagnation layers in cores from the eastern Mediterranean Sea: Verb. Reun. Proc., Monaco.

Trask, P. D., 1939. Organic content of Recent Marine sediments. In Trask, P. D. (Ed.), Recent marine sediments: London (Thomas Murby \& Co.), p. 428-453.

Wasmund, E., 1930. Bitumen, sapropel und gyttja. Geol. Foren. Förhandl., v. 52, Stockholm, p. 315-350.

Wenzlow, B. and Sigl, W., in preparation. Organic geochemistry of Mediterranean sapropels and some paleoenvironmental implications.

\title{
13.3 ORGANIC GEOCHEMISTRY OF SOME NEOGENE CORES FROM SITES 374, 375, 377, AND 378: LEG 42A, EASTERN MEDITERRANEAN SEA
}

\author{
G. Deroo, J. P. Herbin, and J. Roucaché Institut Français du Petrole, 1 et 4 avenue de Bois Preau, \\ 92502 Rueil-Malmaison, France
}

\begin{abstract}
Two different types of organic matter were defined in eastern Mediterranean sediments of late Neogene age which were sampled from cores of the DSDP Leg 42A cruise.

Pyrolysis assay and chloroformic extraction were techniques that were used together with analysis of humic compounds and kerogen fraction. Organic matter from Messinian evaporitic levels of the Ionian Basin (Site 374) could be of marine origin. For the other Neogene samples taken from the Mediterranean Ridge Cleft (Site 377), the Cretan Basin (Site 378), and the Florence Rise (Site $375)$, the organic material mainly originated from continental sources. All the analyzed samples are immature but the samples of Serravallian age from the Florence Rise were the most evolved and had reached the stage of late diagenesis or early catagenesis. It is shown that rich organic black sediments (many of which are referred to as sapropels) may have a number of origins and inferred environments of deposition.
\end{abstract}

\section{INTRODUCTION}

The aim of this paper is to define the different types and the origin of the organic matter in eastern Mediterranean sediments of late Neogene age.

Since burial depths were low and the geological age of the sediments relatively young only minor evolution of hydrocarbons would be expected. Nevertheless geochemical analyses were performed to confirm this point.
A pyrolysis assay for hydrocarbon detection on raw material and some chloroform solvent extractions were first performed. They were useful to characterize ancient sediments. Then followed a study of the remaining insoluble organic fraction on some selected samples. The characterization of the latter is reached from the study of humic compounds on one hand and the kerogen fraction on the other. The elemental composition of kerogen, and the proportion of humic compounds in organic matter give valuable indications as 